\title{
Holocene cooling culminates in sea ice oscillations in Fram Strait
}

\author{
Juliane Müller $^{\mathrm{a}, *}$, Kirstin Werner ${ }^{\mathrm{b}}$, Ruediger Stein ${ }^{\mathrm{a}}$, Kirsten Fahl ${ }^{\mathrm{a}}$, Matthias Moros ${ }^{\mathrm{c}}$, Eystein Jansen ${ }^{\mathrm{d}}$ \\ a Alfred Wegener Institute for Polar and Marine Research, Bremerhaven, Germany \\ ${ }^{\mathrm{b}}$ Leibniz Institute for Marine Sciences, IFM-GEOMAR, Kiel, Germany \\ ${ }^{c}$ Leibniz Institute for Baltic Sea Research, IOW, Rostock, Germany \\ d Bjerknes Centre for Climate Research, University of Bergen, Norway
}

\section{A R T I C L E I N F O}

\section{Article history:}

Received 20 December 2011

Received in revised form

20 April 2012

Accepted 30 April 2012

Available online $\mathrm{xxx}$

\section{Keywords:}

Fram Strait

Sea ice

$\mathrm{IP}_{25}$

Holocene

\begin{abstract}
A B S T R A C T
A reconstruction of Holocene sea ice conditions in the Fram Strait provides insight into the palaeoenvironmental and palaeoceanographic development of this climate sensitive area during the past 8500 years BP. Organic geochemical analyses of sediment cores from eastern and western Fram Strait enable the identification of variations in the ice coverage that can be linked to changes in the oceanic (and atmospheric) circulation system. By means of the sea ice proxy $\mathrm{IP}_{25}$, phytoplankton-derived biomarkers and ice rafted detritus (IRD) increasing sea ice occurrences are traced along the western continental margin of Spitsbergen throughout the Holocene, which supports previous palaeoenvironmental reconstructions that document a general cooling. A further significant ice advance during the Neoglacial is accompanied by distinct sea ice fluctuations, which point to short-term perturbations in either the Atlantic Water advection or Arctic Water outflow at this site. At the continental shelf of East Greenland, the general Holocene cooling, however, seems to be less pronounced and sea ice conditions remained rather stable. Here, a major Neoglacial increase in sea ice coverage did not occur before 1000 years BP. Phytoplankton-IP 25 indices ("PIP 25 -Index") are used for more explicit sea ice estimates and display a Mid Holocene shift from a minor sea ice coverage to stable ice margin conditions in eastern Fram Strait, while the inner East Greenland shelf experienced less severe to marginal sea ice occurrences throughout the entire Holocene.
\end{abstract}

(c) 2012 Elsevier Ltd. All rights reserved.

\section{Introduction}

The extent of sea ice coverage in Fram Strait, the major gateway connecting the Arctic with the Atlantic Ocean, is intrinsically tied to the advection of warm Atlantic Water along the continental margin of West Spitsbergen. As these temperate waters head to the north, they encounter polar water (and air) and sea ice from the Arctic Ocean, which causes cooling, freezing and thus brine rejection, and subsequent descent of Atlantic Water into the Nordic Sea's deep sea basins via the Greenland Sea Gyre (Fig. 1; Aagaard, 1982; Rudels and Quadfasel, 1991; Watson et al., 1999). These processes are of crucial importance for the so-called Nordic heat pump, which bestows a comparatively temperate climate upon Europe (e.g. Broecker, 1992). The climate-shaping impact of sea ice that exits Fram Strait became particularly evident during the "Great Salinity Anomaly" in the 1970s, when an enormous discharge of Arctic sea ice hampered the thermohaline convective overturn in the North Atlantic (in

\footnotetext{
* Corresponding author.

E-mail address: juliane.mueller@awi.de (J. Müller).
}

terms of a vast low salinity freshwater lense), which resulted in a significant cooling in the North Atlantic area (Dickson et al., 1988; Belkin et al., 1998; Dima and Lohmann, 2007; Sundby and Drinkwater, 2007). Recently, Spielhagen et al. (2011) identified and linked natural fluctuations in the advection of Atlantic Water towards Fram Strait with shifting warm and cold climate intervals like the Medieval Climate Anomaly or the Little Ice Age. Furthermore, an unprecedented warming of North Atlantic Water throughout the past 120 years is reconstructed that highlights the importance of the direct feedback mechanisms between the atmospheric (global) warming, the oceanic heat transport through Fram Strait and the sea ice decline in the Arctic realm (Spielhagen et al., 2011). These dynamic interactions account for the Arctic amplification, which impacts not only on the Arctic Ocean but also on adjacent terrestrial (permafrost) areas and finally the global climate system (Lawrence et al., 2008; Serreze and Barry, 2011). Overland and Wang (2010), for example, put emphasis on the loss of Arctic sea ice and the resulting changes in large-scale atmospheric circulation patterns and the consequences for mid-latitude weather (wind) regimes. 


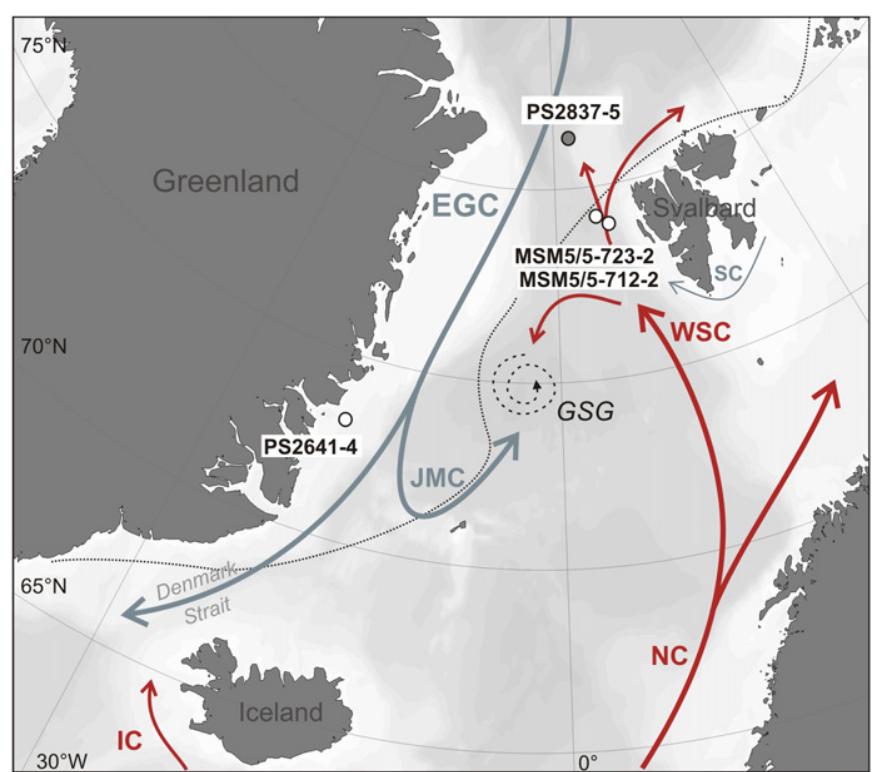

Fig. 1. Oceanographic setting and location of core sites in the study area. Red arrows refer to warm Atlantic Water carried by the Norwegian Current (NC), the Irminger Current (IC), and the West Spitsbergen Current (WSC). Blue arrows refer to polar water and sea ice carried by the East Greenland Current (EGC), the Jan Mayen Current (JMC), and the minor Sørkapp Current (SC). The Greenland Sea Gyre (GSG) and the modern winter sea ice margin (dotted line) are indicated as well. (For interpretation of the references to colour in this figure legend, the reader is referred to the web version of this article.)

The finding of past variations in the sea ice distribution in Fram Strait thus supports the identification of palaeo-fluctuations in the intensity of Atlantic Water inflow and may reveal periods of a strengthened or weakened thermohaline circulation and/or atmospheric (North Atlantic Oscillation; NAO-like) forcing. The influence of the NAO on climate and sea ice conditions in the (sub) Arctic realm frequently has been appraised as fundamental, though hardly assessable or predictable due to its highly variable temporal evolution (e.g. Dickson et al., 2000; Hurrell and Deser, 2010). In short, positive NAO phases are accompanied by stronger westerlies carrying moist air over Europe and Siberia, an increased Atlantic Water inflow through Fram Strait, and warmer temperatures in the Arctic, which lead to a reduction in sea ice formation. During intervals of a negative NAO these phenomena occur to be reversed (Dickson et al., 2000; Kwok, 2000; Hurrell and Deser, 2010). Within their thorough review about Arctic sea ice and its interaction with the atmosphere Bader et al. (2011) illustrate comprehensively how the current sea ice reduction leads to a poleward shift and an intensification of storm tracks, while the immediate impact on the NAO itself remains undetermined. Vice versa, the distinct impact of the NAO on the sea ice extent (e.g. in the Nordic Seas) has been acknowledged and documented more often (Deser et al., 2000; Dickson et al., 2000; Vinje, 2001). Given the lack of instrumental records of the NAO variability prior to 1932 (the first calculation of the NAO index dates back to 1932; Walker and Bliss, 1932) the attempts to link atmospheric fluctuations with climate changes are restricted to proxy reconstructions or numerical model experiments (e.g. Rimbu et al., 2004; Lorenz et al., 2006; Trouet et al., 2012). For instance, an Early to Late Holocene decrease in North Atlantic SSTs is interpreted to reflect a general long-term weakening of the NAO-like atmospheric circulation pattern (Rimbu et al., 2003). On shorter time scales, however, it seems essential to distinguish between the intensity and the frequency of cyclones in the North Atlantic to reasonably relate proxy data to Late Holocene NAO shifts (Trouet et al., 2012).
Though Northern Hemisphere climate (boundary) conditions throughout the Holocene are generally considered as fairly stable (Grootes and Stuiver, 1997), variations in sea surface temperatures (SSTs), glacier growth or terrestrial vegetation communities are increasingly substantiated within marine and terrestrial Arctic palaeoclimate studies (Birks, 1991; Svendsen and Mangerud, 1997; Andersen et al., 2004; for recent review see; Miller et al., 2010). Recently, Risebrobakken et al. (2011) demonstrated reasonably that, when interpreting marine proxy derived climate information (e.g. SSTs) in the Nordic Seas, the individual impacts of orbital forcing (mainly affecting sea surface conditions) and oceanic heat advection (affecting deeper parts of the ocean and convective processes) requires careful consideration as these are different mechanisms of climate change. Thus, the partly contradictory Holocene SST reconstructions in the Nordic Seas, which are based on coccolithophore-derived alkenone or foraminifer data (Calvo et al., 2002; Risebrobakken et al., 2003) can be explained by the simple fact that different proxies may respond to different mechanisms (Risebrobakken et al., 2011).

Concerning sea ice conditions, Holocene changes in the ice coverage in the Nordic Seas, however, have been deduced mainly indirectly from microfossil or geochemical data (Andrews et al., 2001; Jennings et al., 2002; Bonnet et al., 2010). A quantitative approach using diatom transfer functions in the Nordic Seas has been presented by Justwan and Koç (2008). By means of a sediment core north off Iceland, they reconstruct relatively constant sea ice concentrations of ca $5 \%-10 \%$ for the Early Holocene and slightly higher sea ice concentrations of about 10\%-20\% during the Late Holocene (Justwan and Koç, 2008). The application of this promising approach, however, may be limited by the comparatively high silica dissolution rate in the High Northern Latitudes (Kohly, 1998; Schlüter and Sauter, 2000).

The molecular sea ice proxy $\mathrm{IP}_{25}$ - a biomarker lipid associated with sea ice diatoms - seems to be a direct and thus valuable tool for the reconstruction of a previous spring sea ice cover in the Arctic (Belt et al., 2007; Brown, 2011). Besides the identification of highly branched $\mathrm{C}_{25}$ and $\mathrm{C}_{30}$ isoprenoids as diatom specific biomarkers (e.g. Rowland and Robson, 1990; Volkman et al., 1994; Massé et al., 2004) that even may be found in Cretaceous sediments (Damsté et al., 2004), the derivation of the monounsaturated $C_{25}$ highly branched isoprenoid (i.e. the $\mathrm{IP}_{25}$ alkene) from diatoms that live within the Arctic sea ice has been strengthened in various studies (Belt et al., 2008; Brown et al., 2011; Brown and Belt, 2012). With regard to this distinct association of $\mathrm{IP}_{25}$ with sea ice, the detection even of trace abundances of this molecule in a sediment sample, which indeed is a question of instrumental sensitivity, may directly serve as an indication of a previous ice cover. The increasing use of $\mathrm{IP}_{25}$ for palaeo sea ice assessments and its agreement with other proxy (Massé et al., 2008; Müller et al., 2009; Vare et al., 2009, 2010; Belt et al., 2010) and instrumental data (Müller et al., 2011) on sea ice occurrences hence supports the applicability of this biomarker.

In 2009, Vare et al. and Müller et al. presented reconstructions of sea ice conditions based on the $\mathrm{IP}_{25}$ content in sediment cores from the central Canadian Archipelago and northern Fram Strait, respectively, which cover the entire Holocene. Both studies suggest gradually increasing (spring) sea ice occurrences from the Mid to the Late Holocene, presumably as a response to the Neoglacial cooling (Müller et al., 2009), but do not provide an in-depth analysis of the palaeoenvironmental and palaeoceanographic setting. The Neoglaciation - the general use of this term was first suggested by Porter and Denton (1967) - covers the period characterised by glacier advances, southward migration of the northern treeline and colder sea surface conditions in different regions of the Northern Hemisphere that followed the warm Early to Mid Holocene (for 
further review see Wanner et al., 2008; Miller et al., 2010 and references therein).

The main objective of this study is to estimate to what extent this Holocene cooling affected the sea ice distribution in the Fram Strait and the East Greenland shelf. For this purpose, organic geochemical and IRD analyses were performed on sediment cores from the western continental margin of Spitsbergen and the continental shelf of East Greenland. This provides for a reconstruction of the spatial and temporal evolution of the sea ice coverage within the two most important oceanic (in and outlet) pathways that characterise the Fram Strait and influence the Arctic Ocean heat budget. The findings are compared and contextualised with previous palaeoenvironmental reconstructions for the study area.

\section{Regional setting}

The environmental setting in Fram Strait is controlled by a dynamic ocean current system and, owing to the high latitude, a distinct seasonality. Warm and saline Atlantic Water is directed northwards towards Fram Strait by the Norwegian Current (NC) and the West Spitsbergen Current (WSC), thus constituting the northernmost area of open (ice-free) water in the Arctic during winter (Fig. 1; Vinje, 1977; Aagaard, 1982). South of Spitsbergen these temperate waters encounter cold water and sea ice, which is carried by the minor Sørkapp Current (SC) from the Barents Sea along the southern tip and west coast of Spitsbergen (Swerpel, 1985). Further to the north at about $79^{\circ} \mathrm{N}$, the WSC splits in two current systems, with an eastern (Svalbard) branch flowing along the northeastern shelf of Spitsbergen and a western (Yermak) branch following the western flank of the Yermak Plateau where it is partly recirculated southward (Fig. 1; Bourke et al., 1988).

The western part of Fram Strait experiences a huge discharge of polar water and sea ice that originates from the Arctic Ocean (i.e. predominantly from the East Siberian and the Laptev Sea) and is exported along the continental shelf of East Greenland by the East Greenland Current (EGC; Aagaard and Coachman, 1968; Rudels et al., 1999). Currently, only the proximal (inner) shelf of East Greenland and northern Fram Strait remain ice-covered until early summer (NSIDC, Boulder, USA). During periods of extremely cold winter (and spring) months with severe temperature and sea ice conditions in the Arctic, the ice flux may extend towards the east (and south), such that also the eastern part of Fram Strait experiences an intensified (drift) sea ice coverage (for association with NAO variability see Dickson et al., 2000; Vinje, 2001). This is also substantiated through IRD studies of sediment trap material from the continental slope of West Spitsbergen by Hebbeln (2000), who shows that fine-grained lithic material may be released from sea ice originating not only from Spitsbergen but also from the north (i.e. the Arctic Ocean).

\section{Sediment material and methodology}

The sediment cores MSM5/5-712-2 and MSM5/5-723-2 were obtained from the western continental margin of Spitsbergen (at $78^{\circ} 54.94 \mathrm{~N}, 6^{\circ} 46.03 \mathrm{E} ; 1487 \mathrm{~m}$ water depth, and at $79^{\circ} 09.66 \mathrm{~N}$, $5^{\circ} 20.27 \mathrm{E} ; 1349 \mathrm{~m}$ water depth, respectively) during a Maria $S$. Merian cruise in 2007 (Budéus, 2007). The core sites are both located in close vicinity to the modern winter sea ice margin (Fig. 1). Sediment cores were stored at $-30{ }^{\circ} \mathrm{C}$ until further treatment. For organic geochemical analyses subsamples were taken each $\mathrm{cm}$, freeze-dried and homogenised. Sedimentary total organic carbon (TOC) contents were determined by means of a carbon-sulfur determinator (CS-125, Leco) after the removal of carbonates by adding hydrochloric acid. Total carbon (TC) contents measured by a CNS analyser (Elementar III, Vario) were used to calculate carbonate contents $\left(\mathrm{CaCO}_{3}=(\mathrm{TC}-\mathrm{TOC}) \times 8.333\right)$. Core MSM5/5712-2 was further studied for ice rafted detritus (IRD). Lithic grains of freeze-dried subsamples were counted on a representative split (>100 grains) in the $150-250 \mu \mathrm{m}$ size fraction. Further IRD grain size and mineralogy analyses of these cores are subject of a forthcoming study.

Sediment core PS2641-4 from the East Greenland shelf $\left(73^{\circ} 9.3 \mathrm{~N}\right.$, $19^{\circ} 28.9 \mathrm{~W} ; 469 \mathrm{~m}$ water depth) was obtained during Polarstern cruise ARK-X-/2 (Hubberten, 1995). TC and TOC (and thus also carbonate) contents of freeze-dried and homogenised subsamples (5-10 cm sampling intervals) from this core were determined by means of a Heraeus CHN-O-Rapid Elementar Analyser. We note that the freeze-dried sediment material was stored at room temperature for ca 15 years before it was analysed for its biomarker composition. This probably promoted some chemical alteration of the organic matter, which needs to be considered when looking at the absolute concentration profiles of the biomarkers.

For lipid biomarker analyses ca $1-4 \mathrm{~g}$ of sediment were extracted by an Accelerated Solvent Extractor (DIONEX, ASE 200; $\left.100{ }^{\circ} \mathrm{C}, 5 \mathrm{~min}, 1000 \mathrm{psi}\right)$ using dichloromethane:methanol $(2: 1 \mathrm{v} /$ v). Prior to this step, 7-hexylnonadecane, squalane and cholesterol-d6 (cholest-5-en-3 $\beta$-ol-D6) were added as internal standards for quantification purposes. Further separation of alkanes and sterols was carried out via open-column chromatography using $\mathrm{SiO}_{2}$ as the stationary phase. Hydrocarbons were eluted with $n$ hexane $(5 \mathrm{ml})$ and sterols with methylacetate: $n$-hexane $(20: 80 \mathrm{v} / \mathrm{v}$; $6 \mathrm{ml})$. The latter were silylated with $500 \mu \mathrm{BSTFA}\left(60{ }^{\circ} \mathrm{C}, 2 \mathrm{~h}\right)$. Compound analyses of both fractions were carried out on an Agilent 6850 GC (30 m HP-5MS column, $0.25 \mathrm{~mm}$ i.d., $0.25 \mu \mathrm{m}$ film thickness) coupled to an Agilent $5975 \mathrm{C}$ VL mass selective detector. The GC oven was heated from $60{ }^{\circ} \mathrm{C}$ to $150{ }^{\circ} \mathrm{C}$ at $15^{\circ} \mathrm{C} \mathrm{min}^{-1}$, and then at $10{ }^{\circ} \mathrm{C} \mathrm{min}{ }^{-1}$ to $320{ }^{\circ} \mathrm{C}$ (held $15 \mathrm{~min}$ ) for the analysis of hydrocarbons and at $3{ }^{\circ} \mathrm{C} \mathrm{min}{ }^{-1}$ to $320^{\circ} \mathrm{C}$ (held $20 \mathrm{~min}$ ) for sterols, respectively. Operating conditions for the mass spectrometer were $70 \mathrm{eV}$ and $230{ }^{\circ} \mathrm{C}$ (ion source). Helium was used as carrier gas. The identification of individual biomarkers is based upon comparison of their retention times and mass spectra with published data (Boon et al., 1979; Volkman, 1986; Belt et al., 2007). Biomarker concentrations were calculated on the basis of their individual GC-MS ion responses compared with those of respective internal standards. For the quantification of $\mathrm{IP}_{25}$ via its molecular ion a calibration factor was considered that was obtained from calibration experiments using a sediment with known $\mathrm{IP}_{25}$ concentration, which thus serves as a substitute for synthetically produced $\mathrm{IP}_{25}$. The $\mathrm{IP}_{25}$ concentration of this sediment has been verified through GC analyses. Aliquots of the hydrocarbon fraction of this sediment were then used for GC-MS calibration experiments (using a serial dilution), which rest upon correlations of different (quantified via GC) $I_{25}$ concentrations obtained from total ion current analyses with the respective $\mathrm{IP}_{25}$ concentrations determined by selected ion monitoring analyses (m/z 350 for $\mathrm{IP}_{25}$ and $\mathrm{m} / \mathrm{z} 266$ for 7hexylnonadecane). Within this study hydrocarbon fractions from sediment core PS2837-5 (Müller et al., 2009) were re-analysed and their $\mathrm{IP}_{25}$ contents accordingly calibrated, which eases the comparison with the results obtained from core PS2641-4 and the Maria S. Merian cores. The herein presented $\mathrm{PIP}_{25}$ indices are calculated following the equation by Müller et al. (2011), where concentration balance factors are used to account for the disparity between the generally low concentrations of $\mathrm{IP}_{25}$ and the high concentrations (due to multiple phytoplankton sources) of phytoplankton biomarkers in the sediments. Accordingly, the accumulation rates of $\mathrm{IP}_{25}$, brassicasterol, and dinosterol were averaged over the whole core sections and the mean values were then used to calculate the balance factors for the respective cores $\left(\mathrm{PIP}_{25}-\right.$ equations with individual balance factors are also given in Fig. 8). 


\section{Core chronologies}

The chronology of the sediment cores MSM5/5-712-2 and MSM5/5-723-2 is based upon AMS ${ }^{14} \mathrm{C}$ ages obtained from tests of the polar planktic foraminifer Neogloboquadrina pachyderma (sin.), whereas the age model of the sediment core PS2641-4 is based upon AMS ${ }^{14} \mathrm{C}$ ages that were obtained from tests of benthic foraminifera. Additionally, AMS ${ }^{14} \mathrm{C}$ ages were derived from shells of the bivalve Bathyarca glacialis (Evans et al., 2002). For the Maria S. Merian cores a marine reservoir correction of 408 years has been assumed to convert radiocarbon ages into calibrated calendar years before present (cal years BP) using the calibration software CALIB 6 (see Table 1; Stuiver and Reimer, 1993; Stuiver et al., 1998; updated to CALIB 6.0 by Stuiver et al., 2005; see CALIB at http://calib.qub.ac. $\mathrm{uk} /$ ). A reservoir age of 550 years has been assumed for the correction of radiocarbon ages of the PS2641-4 core according to Hjort (1973). For the age model of this core we omitted one ${ }^{14} \mathrm{C}$ age at $90.5 \mathrm{~cm}(1705 \pm 110=1091$ cal years BP $)$ because this sample contained only a very little amount of carbon $(0.06 \mathrm{mg})$. Furthermore, this dating would imply an enormous sedimentation rate $(>500 \mathrm{~cm} / 1000$ years) compared to the adjacent intervals $(<50 \mathrm{~cm} /$ 1000 years). Such an "event" of extreme sediment deposition, however, cannot be identified in the sediment structures of the respective core section. Anticipating linear sedimentation rates at the core sites, ages of sediment intervals between ${ }^{14} \mathrm{C}$-dated horizons are based on linear interpolation (Fig. 2). Mass accumulation rates $\left(\mathrm{g} / \mathrm{cm}^{2} / 1000\right.$ years) were calculated on the base of these sedimentation rates, density and porosity data (Evans, 2000), and were finally used to convert absolute sedimentary biomarker contents into flux rates.

\section{Table 1}

AMS radiocarbon ages for Maria S. Merian cores obtained from tests of the planktic foraminifer Neogloboquadrina pachyderma sin. For these dates a marine reservoir age of 408 years has been assumed according to Hughen et al. (2004). AMS radiocarbon ages for the Polarstern core were obtained from tests of mixed benthic foraminifera. In addition, two AMS ${ }^{14} \mathrm{C}$ dates (labelled with a star) determined in shells of the bivalve Bathyarca glacialis (Evans et al., 2002) were used. For radiocarbon ages of this core a reservoir age of 550 years has been assumed according to Hjort (1973). The age obtained from benthic foraminifera at $90.5 \mathrm{~cm}$ sediment depth in PS2641-4 has been ignored for the calculation of the age model. Superscript numbers in the lab reference indicate ${ }^{14} \mathrm{C}$ dates provided by Robert Spielhagen (1), Jacques Giraudeau (2), Christian Hass (3).

\begin{tabular}{|c|c|c|c|c|}
\hline Sediment core & Lab reference & $\begin{array}{l}\text { Core } \\
\text { depth }(\mathrm{cm})\end{array}$ & AMS ${ }^{14} \mathrm{C}$ age & $\begin{array}{l}\text { Calibrated } \\
\text { age BP }(2 \sigma)\end{array}$ \\
\hline \multirow[t]{9}{*}{ MSM5/5-712-2 } & KIA $45217^{1}$ & 11 & $815 \pm 25$ & $459 \pm 49.5$ \\
\hline & KIA $41024^{1}$ & 21 & $1570 \pm 25$ & $1130 \pm 82.5$ \\
\hline & KIA $45218^{1}$ & 28 & $1985 \pm 25$ & $1544 \pm 96.5$ \\
\hline & KIA $45219^{1}$ & 41 & $2565 \pm 25$ & $2242 \pm 83$ \\
\hline & SacA $19113^{2}$ & 60.5 & $3365 \pm 30$ & $3240 \pm 97.5$ \\
\hline & SacA $19114^{2}$ & 94.5 & $4915 \pm 30$ & $5256 \pm 104$ \\
\hline & SacA $19115^{2}$ & 139 & $6440 \pm 30$ & $6927 \pm 106.7$ \\
\hline & KIA $38080^{1}$ & 169 & $7305 \pm 35$ & $7767 \pm 93.5$ \\
\hline & KIA $41025^{1}$ & 192 & $7815 \pm 45$ & $8285 \pm 97$ \\
\hline \multirow[t]{6}{*}{ MSM5/5-723-2 } & KIA $38738^{3}$ & 11.5 & $675 \pm 25$ & $319 \pm 68$ \\
\hline & KIA $38700^{3}$ & 51.5 & $2125 \pm 25$ & $1714 \pm 93$ \\
\hline & KIA $43851^{3}$ & 102.5 & $3820 \pm 30$ & $3769 \pm 99$ \\
\hline & KIA $38739^{3}$ & 131.5 & $4950 \pm 35$ & $5294 \pm 119$ \\
\hline & KIA $43853^{3}$ & 181 & $6120 \pm 40$ & $6545 \pm 108$ \\
\hline & KIA $38740^{3}$ & 231.5 & $7290 \pm 40$ & $7752 \pm 98$ \\
\hline \multirow[t]{11}{*}{ PS2641-4 } & LuS 8471 & 20 & $995 \pm 60$ & $451 \pm 139$ \\
\hline & LuS 9500 & 43 & $1240 \pm 90$ & $644 \pm 182$ \\
\hline & LuS 8469 & 58 & $1645 \pm 60$ & $1033 \pm 176.5$ \\
\hline & LuS 9124 & 90.5 & $1705 \pm 110$ & $1091 \pm 247$ \\
\hline & LuS 9125 & 128 & $2835 \pm 100$ & $2382 \pm 296.5$ \\
\hline & LuS 9502 & 181.5 & $3775 \pm 150$ & $3519 \pm 407$ \\
\hline & LuS 8468 & 230 & $4625 \pm 60$ & $4640 \pm 198$ \\
\hline & LuS 8470 & 261.5 & $5400 \pm 60$ & $5598 \pm 192$ \\
\hline & AAR-2422* & 375 & $6980 \pm 130$ & $7327 \pm 278.5$ \\
\hline & AAR-2688* & 413 & $7600 \pm 70$ & $7893 \pm 196$ \\
\hline & LuS 8467 & 461.5 & $8415 \pm 80$ & $8783 \pm 256.5$ \\
\hline
\end{tabular}

\section{Results}

\subsection{West Spitsbergen continental margin (cores MSM5/5-712-2} and MSM5/5-723-2)

On the base of our organic geochemical and IRD records the sedimentary sequence of core MSM5/5-712-2 can be separated into three intervals covering the past 8500 years BP (Fig. 3). Results obtained on core MSM5/5-723-2 cover the past 7000 years BP (Fig. 4).

In core MSM5/5-712-2 the late Early Holocene (8500-7000 years BP) is characterised by lowest IRD counts $(<20$ grains per gram sediment), reduced TOC (0.8-1 wt\%) and moderate to maximum $\mathrm{CaCO}_{3}$ contents (10-16 wt\%). Accumulation of phytoplankton-derived biomarkers (dinosterol and brassicasterol; Boon et al., 1979; Volkman et al., 1998) is at its maximum during this interval, whilst the accumulation of the sea ice proxy $\mathrm{IP}_{25}$ becomes significantly reduced after 8300 years BP (Fig. 3). Within this period, at about 8200 years BP, a short-term increase in the IRD content coincides with minimum TOC values and lowered phytoplankton biomarker flux rates. Meanwhile, an abrupt decline in previously high $\mathrm{IP}_{25}$ values is observed between 8300 and 8100 years BP. Further short-term lows in brassicasterol and dinosterol accumulation rates at 7600 and at 7100 years BP are not reflected in the IRD, TOC, or $\mathrm{IP}_{25}$ data (Fig. 3). Maximum $\mathrm{CaCO}_{3}$ contents peak at about 7400 years BP.

During the Mid Holocene (7000-3000 years BP), TOC contents of both Maria $S$. Merian cores reach slightly elevated values (ca $1 \mathrm{wt} \%$ in MSM-5/5-712-2; ca $1.2 \mathrm{wt} \%$ in MSM5/5-723-2) between 6400 and 5800 years BP and between 4200 and 3400 years BP (Figs. 3 and 4). $\mathrm{CaCO}_{3}$ contents of both cores decrease and maintain at minimum values (8-12 wt\%). Continuously decreasing accumulation rates of phytoplankton biomarkers in core MSM5/ 5-712-2, however, are associated with consistently rising IRD and fluctuating $\mathrm{IP}_{25}$ contents throughout this period (Fig. 3). Considerable dinosterol minima occur at about 5000 and 3200 years BP. The $\mathrm{IP}_{25}$ record of core MSM5/5-723-2 shows that a period of slightly higher $\mathrm{IP}_{25}$ flux rates between ca 6200 and 5200 years BP is followed by an $\mathrm{IP}_{25}$ minimum at about 5000 years BP (Fig. 4). Thereafter, a gradual increase in the accumulation of $\mathrm{IP}_{25}$ is observed for the Mid Holocene.

The Late Holocene (3000-300 years BP) is marked by further increasing $\mathrm{TOC}$ and $\mathrm{CaCO}_{3}$ contents in both sediment cores (Figs. 3 and 4). The IRD content in core MSM5/5-712-2 increases as well and reaches maximum values at ca 500 years BP $(>160$ grains per gram sediment; Fig. 3 ). We note that the accumulation of biomarkers in this core is highly variable throughout the past 3000 years (Fig. 3), whereas the increase in $\mathrm{IP}_{25}$ at core site MSM5/5-7232 occurs to be rather gradual and maximum values are reached at about 300 years BP (Fig. 4). In core MSM5/5-712-2 we observe that during intervals of an elevated $\mathrm{IP}_{25}$ accumulation at ca 2800,2300 and 1600 years BP, the flux rates of brassicasterol and dinosterol and also the TOC contents are increased as well (Fig. 3). Vice versa, intermediate periods of lowered $\mathrm{IP}_{25}$ accumulation correspond to periods of reduced phytoplankton marker contents. Divergent from these in-phase fluctuations, we find minimum phytoplankton marker flux rates that coincide with the youngest $\mathrm{IP}_{25}$ peak at about 500 years BP (Fig. 3 ). The TOC content, however, reaches maximum values at this time.

\subsection{Inner East Greenland shelf (core PS2641-4)}

In comparison with the data from core MSM5/5-712-2, we obtained rather monotonous TOC and $\mathrm{CaCO}_{3}$ records from the Holocene section of core PS2641-4 (Fig. 5). TOC contents of 


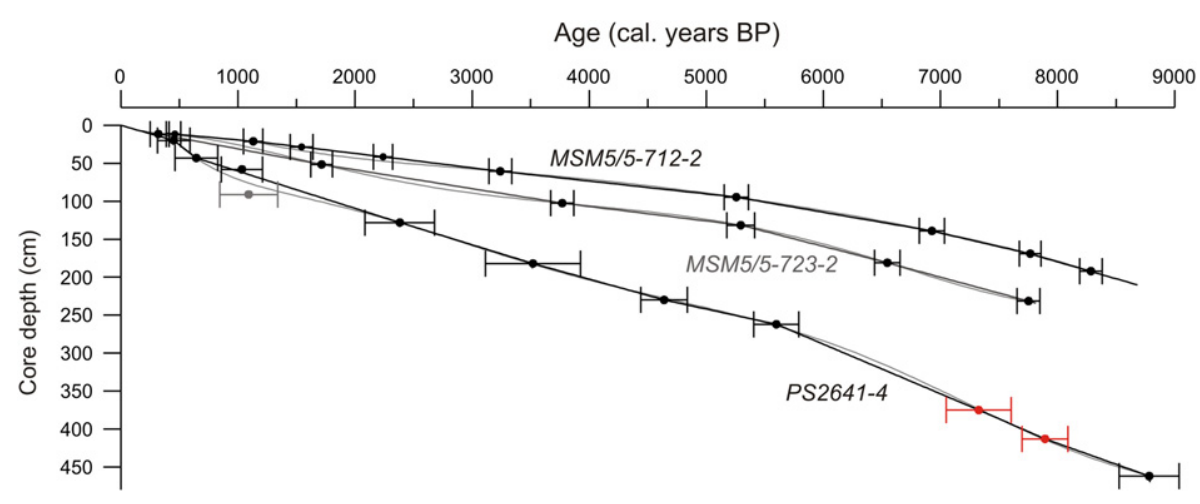

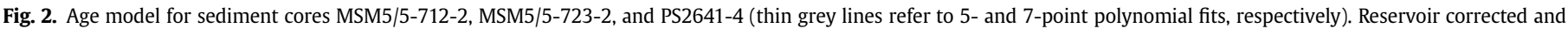

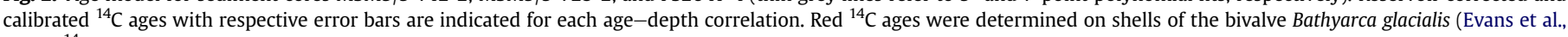

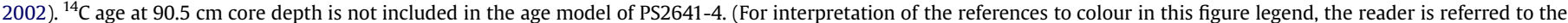
web version of this article.)

0.8-1.3 wt\% remain relatively stable until a distinct increase of similar magnitude than in the cores from the West Spitsbergen slope is observed during the Late Holocene. Notably low $\mathrm{CaCO}_{3}$ contents $(0.3-1.6 \mathrm{wt} \%)$ contrast those of the sediment cores from eastern Fram Strait, and refer to the shift from an Atlantic Water influenced to an EGC dominated sea surface within Fram Strait (Hebbeln and Berner, 1993; Henrich, 1998; Huber et al., 2000). We note that the accumulation rates of biomarkers (in particular of $\mathrm{IP}_{25}$ ) are significantly higher at core site PS2641-4 than at the West Spitsbergen margin, which probably can be attributed to the basically higher mass accumulation at the East Greenland shelf due to ice rafting.

The late Early Holocene (8500-7000 years BP) is characterised by highest $\mathrm{CaCO}_{3}$ contents and elevated phytoplankton marker flux rates, whereas the accumulation of $\mathrm{IP}_{25}$ fluctuates from minimum to moderate values (Fig. 5). The most remarkable feature of the biomarker distribution of this core is a lack of dinosterol and brassicasterol between 7900 and 7600 years BP. This interval seems to interrupt the late Early Holocene section of relatively high phytoplankton marker contents (Fig. 5).

During the Mid Holocene (7000-3000 years BP), the accumulation of phytoplankton biomarkers decreases until ca 5300 years BP and thereafter increases again. Meanwhile, the $\mathrm{IP}_{25}$ flux rate first peaks at about 6000 years BP, then decreases and maintains relatively low values between 5200 and 2300 years BP.

For the Late Holocene, we note an increasing accumulation of brassicasterol, dinosterol, and particularly of $\mathrm{IP}_{25}$ since ca 3000 years BP (Fig. 5). The highest phytoplankton marker contents reach values similar to those seen between 7500 and 6500 years BP. Considerable maxima in all biomarker records and also TOC contents are observed for the past 1000 years BP. $\mathrm{CaCO}_{3}$ contents, in contrast, become successively reduced during the past 1000 years BP.

\section{Discussion}

With the identification of the sea ice biomarker $\mathrm{IP}_{25}$ in the sediment cores MSM5/5-712-2, MSM5/5-723-2, and PS2641-4 we yield novel and direct information about the development of the sea ice conditions along the West Spitsbergen continental margin and the continental shelf of East Greenland throughout the Holocene (Fig. 6). Coincident with the sustained cooling, which is inferred from decreasing $\delta^{18} \mathrm{O}$ values in the NGRIP Greenland ice core (NGRIP-Members, 2004) and a decline in Northern Hemisphere insolation (Laskar et al., 2004), a general upward trend in
$\mathrm{IP}_{25}$ concentrations is observed in the Maria S. Merian cores and also in core PS2837-5 (Fig. 6) located on the Yermak Plateau close to the modern summer sea ice margin (Müller et al., 2009). This increase in $\mathrm{IP}_{25}$ concentrations - most pronounced during the past 3000 years BP - points to a successive (spatial and temporal) extension of the spring sea ice coverage in eastern Fram Strait, possibly due to a lowering of sea surface temperatures (SST). Previous studies from the Nordic Seas and adjacent areas that are based on diatom (e.g. Jiang et al., 2002; Andersen et al., 2004) or foraminifer assemblages (e.g. Slubowska-Woldengen et al., 2007) or alkenone temperatures (Marchal et al., 2002; Sicre et al., 2008) support cooler ocean temperatures during the Late Holocene. Low orbital forcing, reduced Atlantic water advection as well as a higher ice discharge from the Arctic Ocean towards eastern Fram Strait may have promoted such a cooling. $\mathrm{IP}_{25}$ concentrations in core PS2641-4 remain, within a certain range of variability, relatively constant throughout the Holocene until a remarkable increase occurs during the past 1000 years BP (Fig. 6). We thus suggest that a continuous export of Arctic sea ice towards this core site persisted throughout the Holocene but not all changes in this discharge system can be traced in sediments from the inner shelf of East Greenland. The consistent atmospheric cooling recorded in the nearby ice cores from Greenland possibly had no significant net effect on the intensity of the sea ice cover and $\mathrm{IP}_{25}$ sedimentation at core site PS2641-4 until a temperature threshold was reached at 1000 years BP. The previously reported lack of gravel IRD $(>2 \mathrm{~mm})$ in the Holocene section of this core (Evans et al., 2002) thus may relate to the generally low melting rates in the central EGC (preventing iceberg melt/debris release). Hence we assume that a strengthened ice discharge from the Arctic Ocean may have resulted in a broadening of the EGC towards the east, which would not have necessarily intensified the sea ice conditions near the coast of East Greenland. A notably weaker increase in sea ice coverage at the East Greenland shelf (compared to eastern Fram Strait), however, is also described in a palaeo-modelling experiment using NAOSIM (for model details see Kauker et al., 2003) between 6000 years BP and pre-industrial times (supplement to Müller et al., 2011). An influence of the nearby Kejser Franz Joseph Fjord system on the sedimentation regime and hence the biomarker deposition at the inner shelf needs to be considered too.

\subsection{The late Early Holocene (8500-7000 years BP)}

Based on the high phytoplankton biomarker flux rates and minimum $\mathrm{IP}_{25}$ and IRD contents in core MSM5/5-712-2 


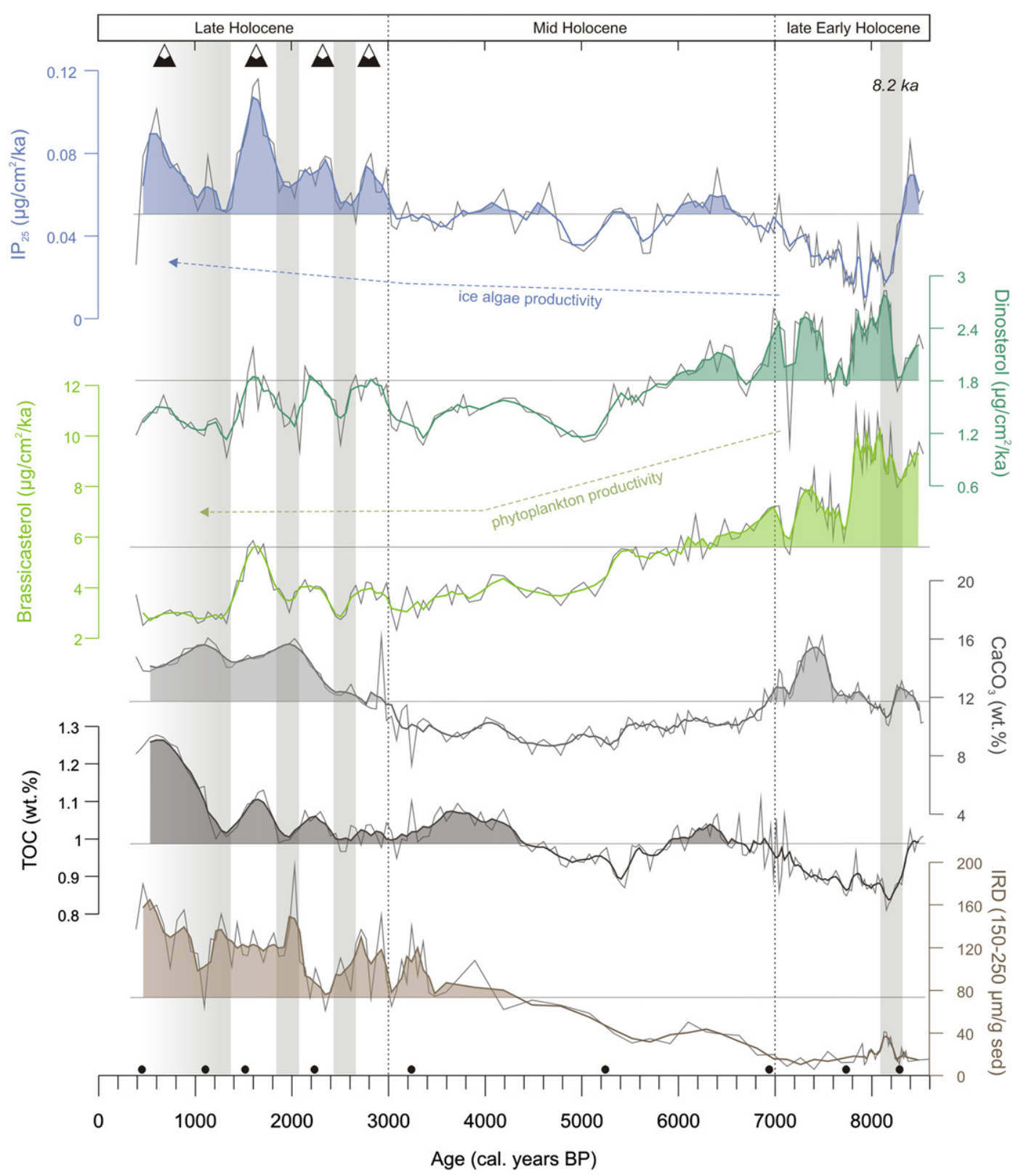

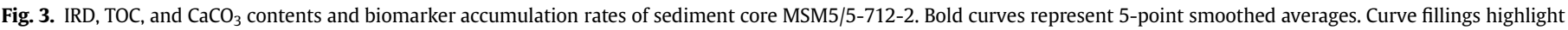

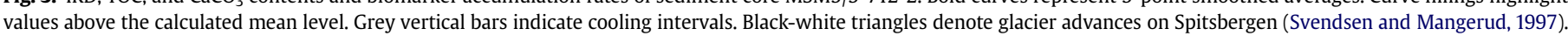
Black dots refer to AMS datings.

comparatively warm sea surface conditions along the West Spitsbergen shelf can be assumed for the late Early Holocene (Fig. 3). This is also supported by the relatively high (even maximum) $\mathrm{CaCO}_{3}$ contents, which, given the low IRD values, may result from a higher productivity of calcareous-walled organisms (e.g. foraminifers, coccoliths) rather than from detrital $\mathrm{CaCO}_{3}$ input. We suggest that this interval represents the latest phase of the Holocene Climate Optimum in eastern Fram Strait and consider that in addition to higher insolation values an intensified Atlantic Water inflow likely supported phytoplankton growth, whereas the (spring) sea ice margin was located further northward (i.e. the core site experienced only minor sea ice occurrences during the late winter/early spring months). This aligns with maximum SSTs reconstructed for the western continental margin of the Barents Sea by Sarnthein et al. (2003) and findings of Salvigsen et al. (1992), who report optimum climate conditions for thermophilous molluscs on western Svalbard for the period between 8700 and 7700 years BP. Likewise, foraminifer-based reconstructions of ocean circulation changes along the West Spitsbergen shelf by Slubowska-Woldengen et al. (2008) reveal a strengthened inflow of Atlantic Water at that time.

The abrupt reductions in the phytoplankton marker contents of core MSM5/5-712-2 at about 8300,7600 and 7100 years BP that punctuate the late Early Holocene probably point to short-term deteriorations of the sea surface conditions. Since the decline at ca 8200 years BP - a prominent cooling event in the High Latitudes (Alley et al., 1997; Clarke et al., 2004; Kleiven et al., 2008) - coincides with a (somewhat retarded) minor short-term increase in IRD and a rapid decrease of previously high $\mathrm{IP}_{25}$ contents, we assume that the core site was affected by a massive ice discharge that 


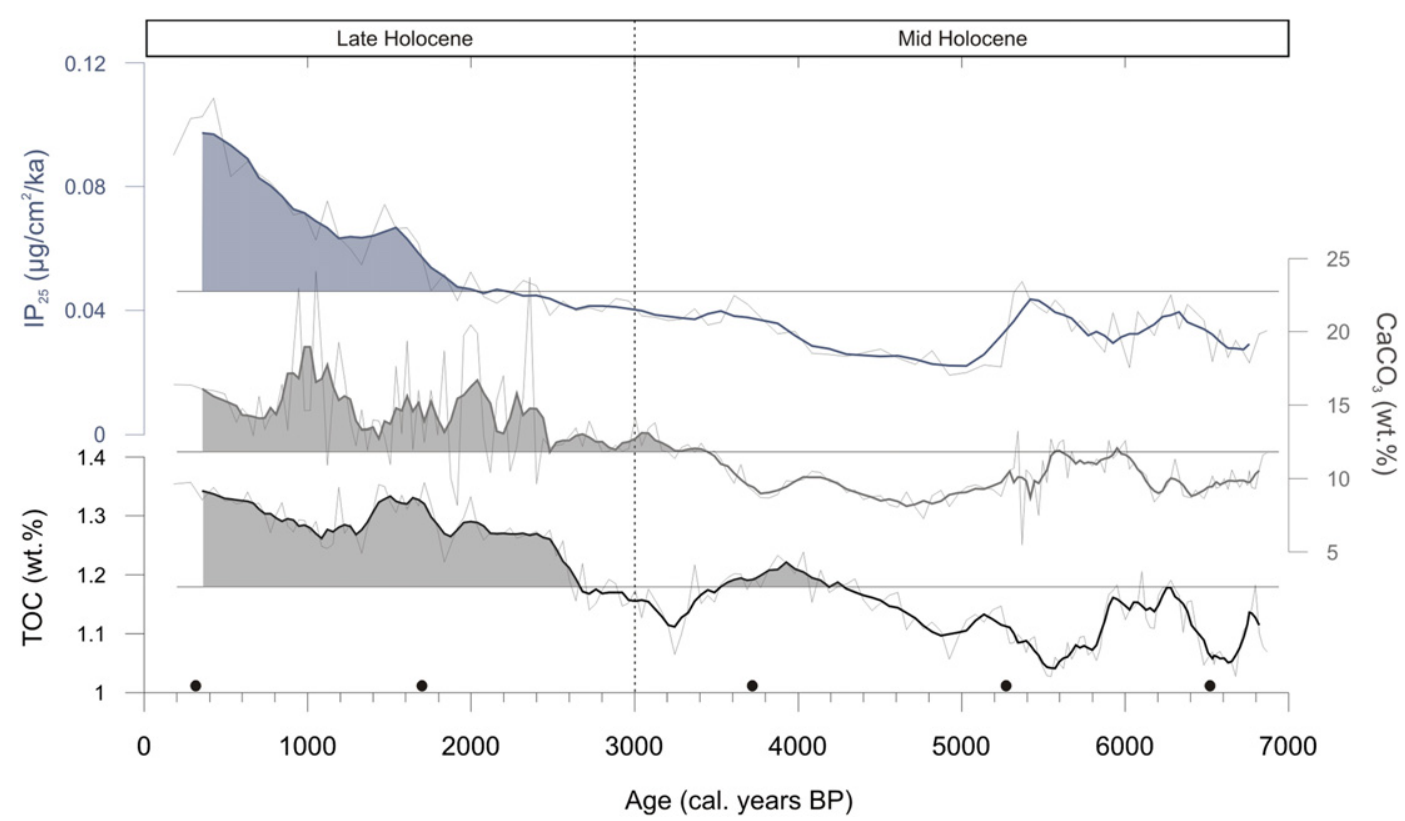

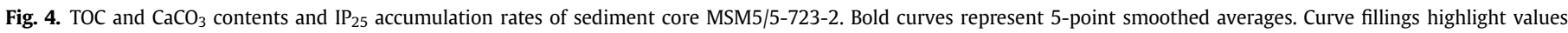
above the calculated mean level. Black dots refer to AMS datings.

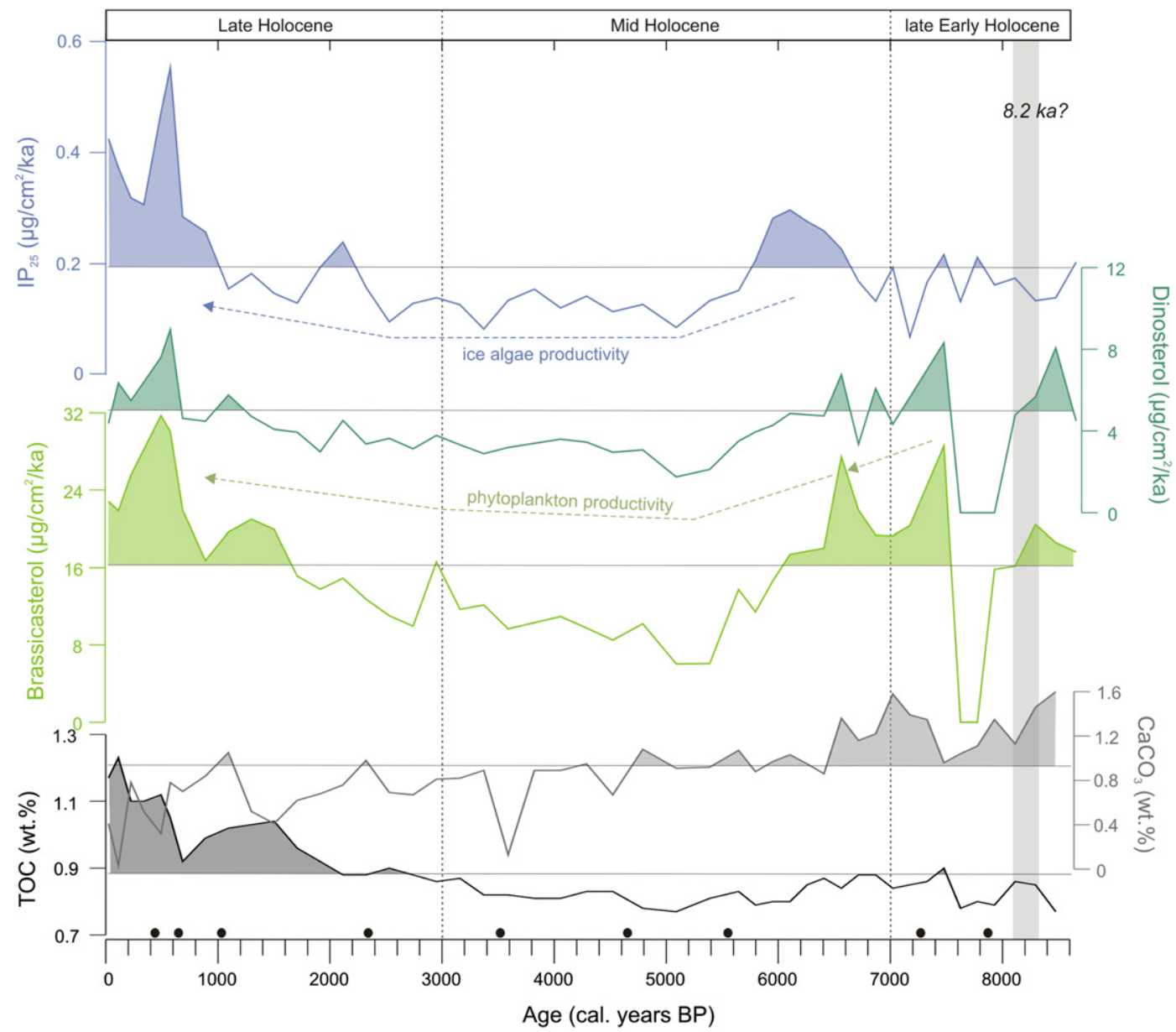

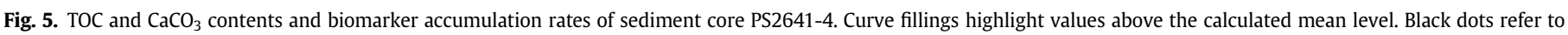
AMS dating points. 


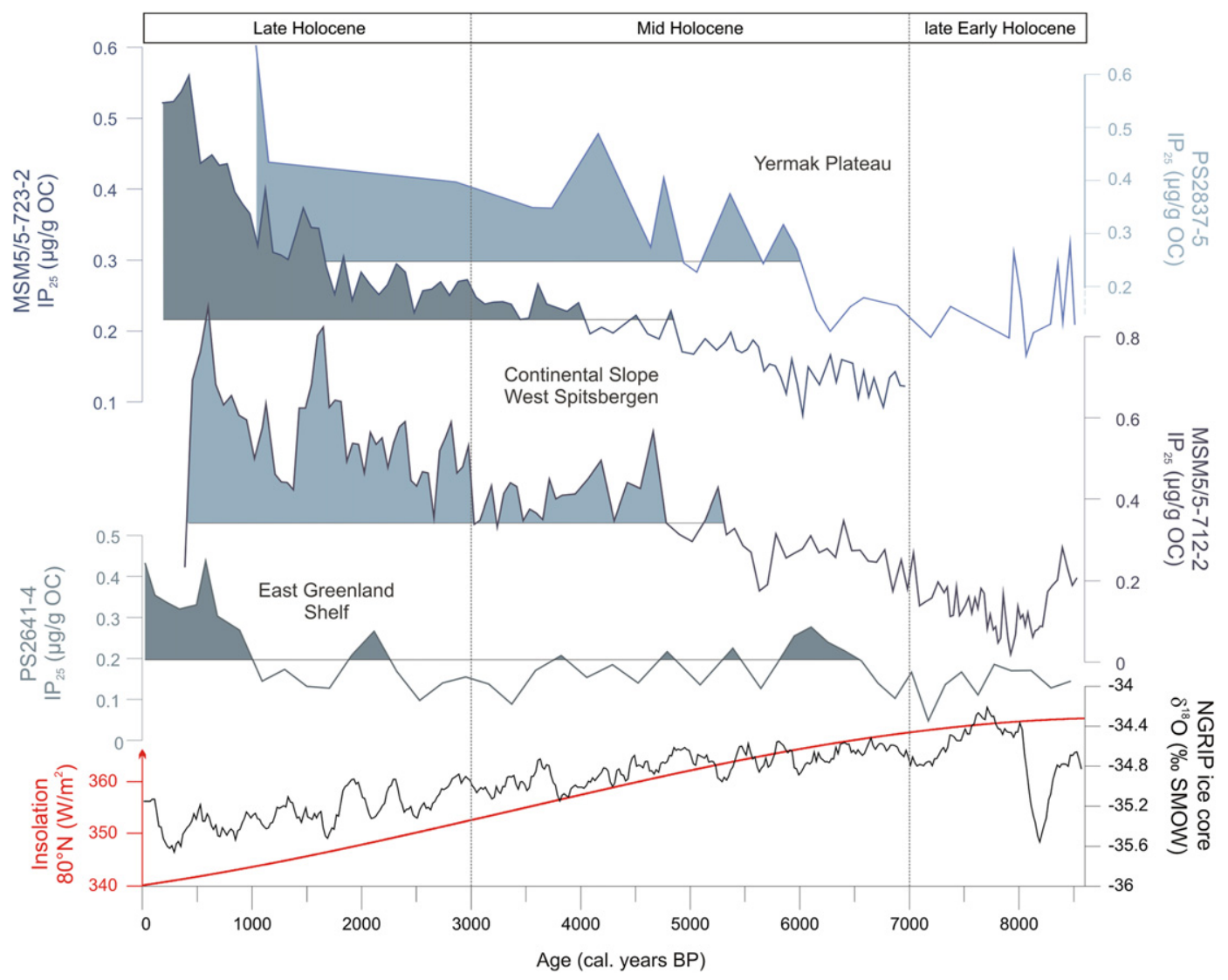

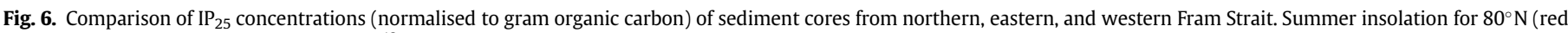

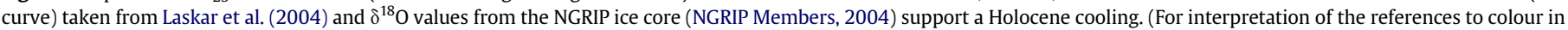
this figure legend, the reader is referred to the web version of this article.)

reduced not only the growth of phytoplankton but also that of ice algae. This agrees with reduced SSTs along the Barents Sea margin for this period (Sarnthein et al., 2003). Similarly, Müller et al. (2009) interpreted minimum fluxes of $\mathrm{IP}_{25}$ and brassicasterol as indicative for a near-perennial sea ice cover at the western Yermak Plateau in northern Fram Strait at about 8200 years BP.

Relatively warm conditions probably also prevailed along the East Greenland shelf during the late Early Holocene since at core site PS2641-4 accumulation rates are relatively high for dinosterol and brassicasterol, and only moderate for $\mathrm{IP}_{25}$ (Fig. 5), which may point to a reduced (not absent) ice cover at the inner East Greenland shelf. Minor sea ice cover, a higher release of nutrient rich freshwater from the melting Greenland ice sheet and changes in the local (Fjord) circulation system thus may have promoted the growth of phytoplankton. Similarly, e.g. Bauch et al. (2001) and Andersen et al. (2004) reconstruct rather warm sea surface conditions in the central Nordic Seas and at the East Greenland shelf for the late Early Holocene by means of foraminifer and diatom assemblages. This period likely corresponds to the retreat of the Greenland ice sheet from the inner shelf as is reconstructed by Evans et al. (2002) on base of sediment lithology and $\delta^{18} \mathrm{O}$ data from core PS2641-4. The sudden lack of the phytoplankton markers between 7900 and 7600 years BP could point to a short-term deterioration in sea surface conditions, which is not reflected in the $\mathrm{IP}_{25}$ contents (Fig. 5). Increased meltwater discharge from the adjacent Kejser Franz Joseph Fjord either could have caused a strong stratification of the upper water layer, thus reducing the ventilation and availability of nutrients required for phytoplankton growth or, in contrast, it may have increased the turbidity, which may suppress phytoplankton productivity as well. Another possibility would be that local sea ice formation benefited from the episodic release of cold and fresh meltwater from the Greenland ice sheet. If this was the case, however, we do not see a notable effect on the accumulation of $\mathrm{IP}_{25}$.

\subsection{The Mid Holocene (7000-3000 years BP)}

Lowered $\mathrm{CaCO}_{3}$ contents, continuously decreasing accumulation rates of phytoplankton markers, the sustained increase in IRD and slightly higher $\mathrm{IP}_{25}$ contents in sediment core MSM5/5-712-2 (and MSM5/5-723-2; Figs. 3 and 4) point to a gradually reduced phytoplankton productivity due to a cooling of the sea surface and a successive growth and extension of (winter/spring) sea ice at the continental slope of West Spitsbergen during the Mid Holocene. This agrees with a concurrent increase in IRD contents of sediment cores along the West Spitsbergen continental shelf and margin documented by Jessen et al. (2010) and Slubowska-Woldengen et al. (2007), who assume a Mid Holocene ice advance. Decreasing SSTs off and enhanced glaciation on West Spitsbergen (Hald et al., 2004) support this interpretation. To what extent this Holocene cooling trend observed in the subpolar North Atlantic domain (e.g. Andersen et al., 2004; Hald et al., 2007; Miller et al., 2010) may be related to the lowered Northern Hemisphere insolation and/or a reduced Atlantic Water advection and/or changes in the atmospheric circulation remains unknown. A general recovery of the Arctic's sea ice after its significant recession during the Holocene Climate Optimum (see e.g. Polyak et al., 2010 for review), however, occurs as a plausible and natural response to the 


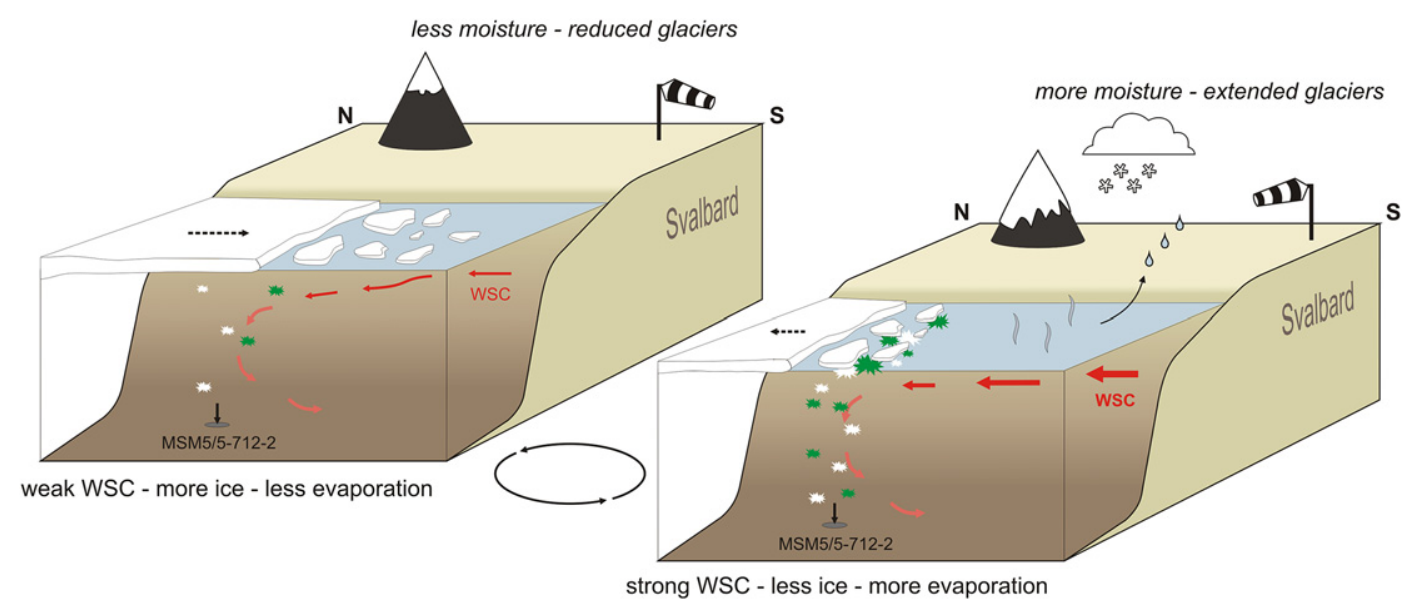

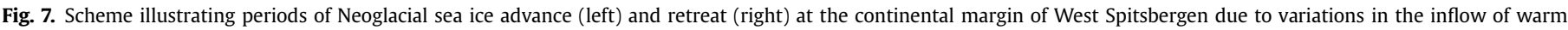

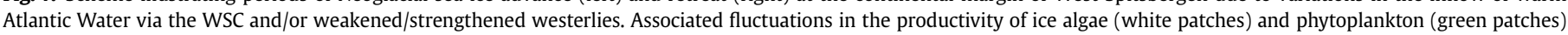

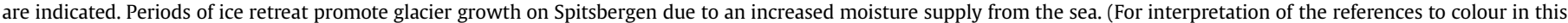
figure legend, the reader is referred to the web version of this article.)

mitigation of orbital forcing. Sustained oceanic surface cooling that stimulated the sea ice formation during winter and retarded its retreat/melt during the late spring and early summer months is also supported by e.g. Rasmussen et al. (2007) and Jennings et al. (2002) who reconstruct increasingly cooler conditions along the West Spitsbergen shelf and an increased sea ice export through Fram Strait by means of benthic and planktic foraminifera and IRD records. Furthermore, on the bases of e.g. increasing $\delta^{18} \mathrm{O}$ values, increasing abundances of $N$. pachyderma (sin.) and diatom data, Rasmussen et al. (2007), Bauch et al. (2001) and Koç et al. (1993) strengthen that the southwestern continental margin of Spitsbergen and the Nordic Seas experienced an intensified water mass exchange with the Arctic Ocean for the period after 7000 years BP and continuous surface cooling (in-step with the lowered insolation) since ca 6000 years BP. Reduced winter SSTs are also reconstructed for the western continental margin of the Barents Sea and have been related to a weakened heat input with the WSC and a strengthened East Spitsbergen (Sørkapp) Current leading to periods of extended sea ice coverage (Sarnthein et al., 2003).

Successively reduced phytoplankton marker contents in core PS2641-4 indicate that also the East Greenland shelf became gradually cooled between ca 6600 and 3000 years BP (Fig. 5). A higher accumulation of $\mathrm{IP}_{25}$ around 6000 years $\mathrm{BP}$ may point to an increase in sea ice cover at this time. Similarly, Ran et al. (2006) interpret higher abundances of Arctic diatom taxa in a sediment core from the northern shelf of Iceland as indicative of a strengthening of the EGC between 6800 and 5500 years BP. The subsequent relatively low and uniform (i.e. with some minor fluctuations) $\mathrm{IP}_{25}$ and phytoplankton marker flux rates, however, suggest that largely constant sea ice conditions prevailed at the inner East Greenland shelf between 5000 and 2500 years BP. Recent reconstructions by Jennings et al. (2011) document that an intensified Irminger Current carried more warm Atlantic Water to Denmark Strait between 6800 and 3500 years BP. This could be related to a weakening of the EGC during this period, but is not reflected in the $\mathrm{IP}_{25}$ or phytoplankton marker data at our core site, which may reveal an influence of the nearby Fjord circulation and sedimentation processes. Moros et al. (2006), in turn, observe a long-term trend of increasing drift ice export via the EGC towards the North Atlantic since the past 5000 years. With respect to our biomarker data, we suggest that Mid Holocene variations in the strength or extent of the EGC, however, are not clearly recorded in sediments from the inner shelf but rather could be traced at the outer shelf of East
Greenland where the environment is less affected by Fjord conditions.

\subsection{The Late Holocene (the past 3000 years BP)}

Maximum IRD release and a sustained increase in the accumulation of $\mathrm{IP}_{25}$ during the past 3000 years - a period that is widely acknowledged as Neoglacial cooling phase (for recent review see Miller et al., 2010) - point to intensified sea ice occurrences at the West Spitsbergen continental margin. Forwick and Vorren (2009) and Forwick et al. (2010) assume an enhanced formation of shore-fast sea ice and/or a permanent sea ice cover along the West Spitsbergen coast that trapped IRD laden icebergs within the Isfjorden system during the past ca 4000 years BP. Thus, the elevated IRD contents at core site MSM5/5-712-2 may suggest a transport of lithic grains by sea ice rather than by icebergs originating from Spitsbergen glaciers. Further reconstructions of gradually cooled sea surface temperatures, lowered productivity and a higher polar water ouflow to the Nordic Seas during the past 3000 years BP support this general increase in sea ice coverage (Koç et al., 1993; Andrews et al., 2001; Calvo et al., 2002; Jennings et al., 2002, 2011; Andersen et al., 2004).

We suggest that the in-phase fluctuations of $\mathrm{IP}_{25}$ and phytoplankton marker contents in core MSM5/5-712-2 (Fig. 3) can be attributed to periods of a rapidly advancing and retreating sea ice margin at this core site until ca 1200 years BP. Accordingly, the less variable though steadily rising accumulation of $\mathrm{IP}_{25}$ at core site MSM5/5-723-2 - ca $40 \mathrm{~km}$ further to the north of core site MSM5/ 5-712-2 - relates to a continuously increasing ice coverage during the past 3000 years BP. As marine primary productivity is demonstrably stimulated in the marginal ice zone (release of nutrients from the melting sea ice triggers the bloom of the phytoplankton algae in the proximity of the ice edge; Hebbeln and Wefer, 1991; Ramseier et al., 1999; Sakshaug, 2004; Smith et al., 1987), we conclude that the periods of peak $\mathrm{IP}_{25}$ and phytoplankton marker contents in core MSM5/5-712-2 at about 2800, 2300 and 1600 years BP reflect beneficial living conditions at the ice edge for both sea ice algae and plankton thriving in open water (Müller et al., 2009, 2011). Interestingly, Svendsen and Mangerud (1997) report concurrent (with minor temporal shifts) periods of abrupt glacier advances on West Spitsbergen. Since glacier growth requires a higher winter precipitation (and the main moisture source for the Svalbard archipelago is the subpolar North Atlantic; 
Dickson et al., 2000; Humlum et al., 2005), we hence assume that these intervals of glacier advance and ice edge conditions at the core site may have been triggered by a temporarily strengthened WSC and/or changes in the atmospheric circulation pattern, which caused these recurrent northward retreats of the sea ice cover (Fig. 7). This is also supported by findings of Sarnthein et al. (2003) who identify two intervals of remarkably warmer SSTs and peak abundances of the foraminifer Turborotalita quinqueloba at the western continental margin of the Barents Sea at about 2200 and 1700 years BP, which they attribute to short-term pulses of warm Atlantic Water advection. Intermediate periods of lowered $\mathrm{IP}_{25}$ and phytoplankton marker contents accordingly point to a weakened WSC - weakened through a lowered heat and/or volume transport - and probably an increased ice discharge from the Arctic Ocean that permitted sea ice advances beyond the core site (Fig. 7). Intensified sea ice advection via the Sørkapp Current is possible as well. Such a fluctuating ice margin (due to a variable Atlantic Water inflow) is also described in a recent study by Werner et al. (2011) on the bases of foraminifer and IRD data obtained from a box core that was recovered at the same core site. Both short-term anomalies in atmospheric pressure fields (controlling the intensity and strength of wind and oceanic sea surface current patterns) or even variations in the thermohaline circulation may have caused these sea ice fluctuations. Given the comparatively "sluggish" behaviour of thermohaline convection processes, the latter, however, appears to be a less probable explanation for such rapid oscillations.

The notably reduced accumulation of dinosterol and brassicasterol in core MSM5/5-712-2 during the past 1300 years BP may indicate a deterioration of the sea surface conditions that limited the productivity of phytoplankton at the West Spitsbergen margin. Meanwhile increasing $\mathrm{IP}_{25}$ flux rates and highest IRD contents at about 600 years $\mathrm{BP}$ suggest an increase in sea ice coverage and the occurrence of icebergs that probably carried organic material, which could account for maximum TOC values. The possibility that a general increase in sea ice algal blooms during spring could account for this increase in TOC may be considered too. The Late Holocene maximum content of $\mathrm{CaCO}_{3}$ thus could be related to a higher productivity of calcareous-walled plankton grazing on ice algae if it is not due to a higher input of calcareous IRD. Maximum $\mathrm{IP}_{25}$ concentrations in sediment core MSM5/5-723-2 (Fig. 4), however, support this Late Holocene sea ice advance.

In contrast to the finding for eastern Fram Strait, the stepwise increase in $\mathrm{IP}_{25}$ flux rates at the East Greenland shelf since 2500 years BP is accompanied by a continuously rising accumulation of brassicasterol and dinosterol (Fig. 5). The onset of this increase in $\mathrm{IP}_{25}$ aligns with findings of Sicre et al. (2008), who document that at about 2500 years BP a trend of slightly warmer SSTs north off Iceland was reversed by a cooling tendency towards present. The short interval of warmer SSTs during the Medieval Warm Period (around 1000 years BP), however, is not clearly distinguishable in core PS2641-4. Instead, maximum fluxes of $\mathrm{IP}_{25}$ and phytoplankton biomarkers point to favourable living conditions for both ice and phytoplankton algae at the East Greenland shelf during the past 1000 years BP. Further reduced $\mathrm{CaCO}_{3}$ contents in this core hence may possibly be attributed to calcium carbonate dissolution due to an increased formation of corrosive bottom waters linked to higher sea ice production and/or organic matter (originating from phytoplankton blooms) remineralisation (Steinsund and Hald, 1994). Alternatively, this reduction in $\mathrm{CaCO}_{3}$ may indicate a shift of the provenance of ice rafted (carbonate) material. The highest $\mathrm{IP}_{25}$ contents determined for the past 600 years BP in all cores are tentatively attributable to the 'Little Ice Age' cooling that is also recorded in further marine (e.g. Andersson et al., 2003; Moros et al., 2006; Bendle and Rosell-Melé, 2007; Spielhagen et al., 2011) and also terrestrial archives from the subpolar North Atlantic (e.g. Nesje et al., 2001; Seppä and Birks, 2002). The occurrence of a broad and severe (i.e. perennial) sea ice cover during this period, however, seems to be contradicted by the elevated phytoplankton marker contents in core PS2641-4. We hence conclude that during the past ca 600 years BP, stable marginal ice zone (probably polynya-like) conditions established at the inner East Greenland shelf, whereas eastern Fram Strait experienced an ice advance that reduced phytoplankton productivity. Assumptions that this 'Little Ice Age' North Atlantic cooling may result from a weakening of the Gulf Stream and a slowing of the thermohaline circulation (Broecker, 2000; Lund et al., 2006) would support the interpretation of high $\mathrm{IP}_{25}$ and IRD contents in sediments from the West Spitsbergen slope as indicative of an extended ice cover at these sites. The preceding 'Medieval Warm Period', however, is not reflected (or resolved) in the biomarker records, though we note a short-term decrease in IRD in MSM5/5-712-2 at about 1100 years BP suggesting reduced iceberg occurrences.

\subsection{Sea ice fluctuations and North Atlantic Oscillation}

With respect to the Late Holocene cooling that is observed at various sites in the subpolar North Atlantic and also in more remote areas, the hypothesis evolved that a continuous transition from a positive towards a negative NAO phase characterised the Holocene climate development (e.g. Andersen et al., 2004). Reduced Siberian river discharge during the past 2000 years BP and vegetation changes in northeast European Russia, for example, are interpreted to reflect the development of a colder and dryer climate in the Eurasian Arctic and could be related to negative NAO-like conditions (Stein et al., 2004; Salonen et al., 2011). And also Jessen et al. (2011) relate changes in Late Holocene pollen records from southern Greenland and the Labrador Sea to a distinct reduction of south-westerly air masses in favour of colder air originating from the north and thus conclude that the atmospheric circulation pattern in the subpolar North Atlantic likely shifted from a more positive to a more negative NAO. Sicre et al. (2008) attribute short-term SST changes off North Iceland during the Late Holocene to low frequency NAO forcing that partly seems to be associated with fluctuations in the meridional overturning circulation (Latif et al., 2006) and thus (large-sale) alterations in the Atlantic hydrological cycle. Regarding the comparatively rapid sea ice oscillations at core site MSM5/5-712-2 between 3000 and 1200 years BP, we consider that a relationship between sea ice extent and oceanic-atmospheric (i.e. NAO-like) forcing fields, in fact, could explain the observed fluctuations. As no (instrumental) records of the long-term (centennial- to millennial-scale) development of the NAO are available, its influence on Late Holocene environmental conditions in the subpolar North Atlantic remains elusive. Proxyand model-based reconstructions of NAO conditions (e.g. Luterbacher et al., 2001; Trouet et al., 2009 and references therein) thus may provide valuable palaeoenvironmental information, though they are mainly confined to the past 1000 years BP depending on the availability of respective proxy data for calibration. Trouet et al. (2009), for example, find that the 'Medieval Warm Period' was associated with a positive NAO mode, while a negative mode prevailed during the 'Little Ice Age'. A genuine attempt to directly compare (and link) the biomarker fluctuations in core MSM5/5-712-2 during the past 3000 years with reconstructed NAO indices proves problematic as no NAO reconstructions are available for this time period. Shifting NAO conditions, however, could account for respective changes in the strength of westerly storm tracks and Atlantic Water advection to the continental margin of Spitsbergen (Kwok and Rothrock, 1999; Dickson et al., 2000; Hurrell and Deser, 2009). Neglecting the temporal resolution of this core ( $1 \mathrm{~cm}$ represents ca 40 years) and that $\mathrm{IP}_{25}$ fluctuations follow 
a rather multi-centennial than an annual to decadal (NAO-specific) pattern, we may link our findings with atmospheric circulation shifts. Positive NAO-like conditions could have prevailed during periods of elevated $\mathrm{IP}_{25}$ and phytoplankton biomarker contents and glacier advances on Spitsbergen, while a negative NAO-like forcing may have promoted the recurrent southward advances of sea ice that punctuated these ice edge productivity intervals. Previously, the observation of fluctuating glacier extents in southwest Norway lead Nesje et al. (2001) and Imhof et al. (2012) to establish a relationship between Late Holocene glacier advances and positive NAO phases causing more humid and wet winter conditions over Scandinavia. Similarly, Giraudeau et al. (2010) credit both an increased advection of Atlantic Water into the Norwegian Sea and a coincidently strengthened polar outflow towards the western Nordic Seas to positive NAO intervals during the Late Holocene. Such a seesaw pattern between warm water input through eastern and cold water output via western Fram Strait, however, is not observed in our records. With general regard to the Holocene climatic development, we notice that the sea ice conditions at core site PS2641-4 obviously were less prone to variations in the strength of the oceanic (and atmospheric) circulation system than the sites in eastern Fram Strait. The rapid sea ice fluctuations reflected in the record of core MSM5/5-712-2 during the past 3000 years BP and the likely associated changes in the advection of warm (WSC) and polar (EGC) water masses are not fully traceable in the record of core PS2641-4. Due to its location in the vicinity of the Arctic and Atlantic oceanic (and atmospheric) fronts, core MSM5/5712-2 apparently experienced more significant palaeoceanographic and environmental changes, while the setting at the inner shelf of East Greenland remained relatively unaffected.

\subsection{PIP $_{25}$ index and sea ice estimate}

We recently demonstrated that the coupling of the environmental (sea surface) information carried by $\mathrm{IP}_{25}$ and phytoplankton biomarkers by means of a phytoplankton-IP 25 index $\left(\mathrm{PIP}_{25}\right)$ proves a valuable approach for quantitative reconstructions of (spring) sea ice coverage (Müller et al., 2011). A distinct connection between the sea ice distribution and sedimentary $\mathrm{IP}_{25}$ and phytoplankton marker contents is strengthened through correlation analyses of $\mathrm{PIP}_{25}$ indices determined on surface sediments from the subpolar North Atlantic with sea ice concentrations derived from satellite and modelling data (Müller et al., 2011). According to the respective phytoplankton biomarker used for the calculation (brassicasterol or dinosterol), this index is specified as $\mathrm{P}_{\mathrm{B}} \mathrm{IP}_{25}$ or $\mathrm{P}_{\mathrm{D}} \mathrm{IP}_{25}$, respectively. Highest $\mathrm{PIP}_{25}\left(\mathrm{P}_{\mathrm{B}} \mathrm{IP}_{25}\right.$ and $\left.\mathrm{P}_{\mathrm{D}} \mathrm{IP}_{25}\right)$ values in the range of $0.75-1$ seem to reflect extended ice coverage throughout spring and summer, whilst minimum values refer to predominantly ice-free (spring/ summer) sea surface conditions. Intermediate values $(0.5-0.75)$ characterise sites within the productive marginal ice zone.

Throughout the past 8000 years $\mathrm{BP}, \mathrm{P}_{\mathrm{B}} \mathrm{IP}_{25}$ and $\mathrm{P}_{\mathrm{D}} \mathrm{IP}_{25}$ indices calculated for core MSM5/5-712-2 sediments rise gradually (Fig. 8) and thus point to a general increase in (spring) sea ice coverage at the West Spitsbergen continental margin. Minimum and close to zero values denote a period of significantly reduced ice cover between 8200 and 7800 years BP. With reference to the findings of Müller et al. (2011) these values may refer to a sea ice concentration of less than $20 \%$. Given the infancy of this approach, this interpretation of $\mathrm{P}_{\mathrm{B}} \mathrm{IP}_{25}$ and $\mathrm{P}_{\mathrm{D}} \mathrm{IP}_{25}$ values in terms of sea ice concentrations, however, needs to be considered as a very rough estimate. A sustained increase in sea ice occurrences at the core site is reflected by further rising $\mathrm{P}_{\mathrm{B}} I \mathrm{P}_{25}$ and $\mathrm{P}_{\mathrm{D}} \mathrm{IP}_{25}$ values, which finally pass the "threshold level" of 0.5 designating marginal ice zone conditions from ca 4800 years $\mathrm{BP}$ on. Maximum $\mathrm{P}_{\mathrm{B}} \mathrm{IP}_{25}$ values determined for the past ca 1000 years are in the range of $0.75-0.80$ and thus indicate a shift towards severe ice coverage (presumably $>70 \%$ ice concentration).

$\mathrm{P}_{\mathrm{B}} \mathrm{IP}_{25}$ and $\mathrm{P}_{\mathrm{D}} \mathrm{IP}_{25}$ indices calculated for core PS2641-4 show minimum values during the late Early Holocene (8700-7200 years BP; Fig. 8) that point towards a variable or less pronounced sea ice coverage at the inner shelf of East Greenland. Given the lack of brassicasterol and dinosterol between 7900 and 7600 years BP, $\mathrm{P}_{\mathrm{B}} \mathrm{IP}_{25}$ and $\mathrm{P}_{\mathrm{D}} \mathrm{IP} \mathrm{P}_{25}$ values are 1 for this interval, which would refer to a significantly extended (spatially and temporally) ice cover. Throughout the past 7000 years $\mathrm{BP}, \mathrm{P}_{\mathrm{B}} \mathrm{IP}_{25}$ and $\mathrm{P}_{\mathrm{D}} \mathrm{IP}_{25}$ indices of core PS2641-4 fluctuate between values of ca 0.4 to 0.6 (Fig. 8), which
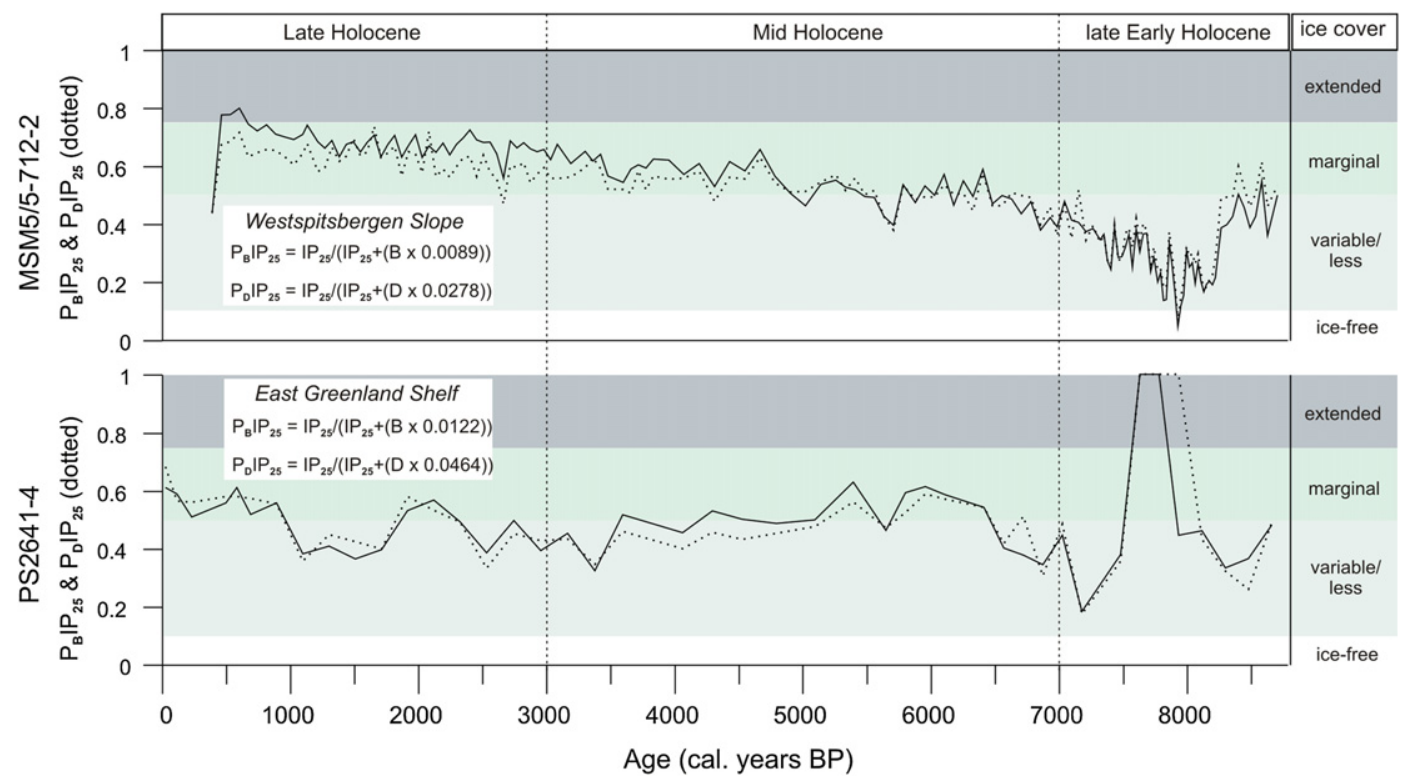

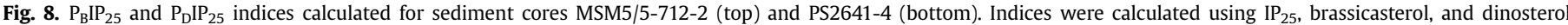

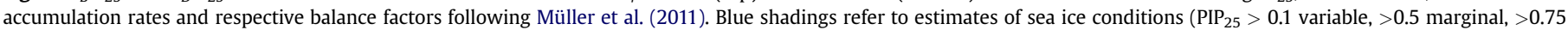

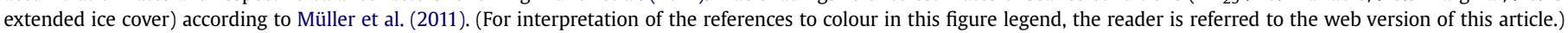


may denote variable to stable marginal sea ice conditions (20-50\% ice concentration) in western Fram Strait throughout the Mid and Late Holocene. The observation that $\mathrm{P}_{\mathrm{B}} \mathrm{IP} \mathrm{P}_{25}$ and $\mathrm{P}_{\mathrm{D}} \mathrm{IP}_{25}$ indices obtained from this core are largely in the same range or even lower than those from core MSM5/5-712-2 occurs somewhat surprising as sea ice conditions at the East Greenland shelf are generally considered to be more severe due to the pronounced discharge of sea ice and icebergs via the EGC. In a previous study, the absence of coarse-grained IRD in the PS2641-4 sediments has been interpreted to reflect a sedimentation regime that is dominated by meltwater discharge rather than by iceberg rafting (Evans et al., 2002). This prompts the assumption that much of the brassicasterol and dinosterol identified in this core could originate from the adjacent Fjord systems and is advected through massive meltwater releases in summer. In fact, higher concentrations of algae-specific fatty acids, brassicasterol and dinosterol (pointing to a higher phytoplankton productivity) are observed in the surface sediments from different East Greenland Fjords compared to sediments from the East Greenland shelf at similar latitude (Kierdorf, 2006; Müller et al., 2011). While calculating the $\mathrm{P}_{\mathrm{B}} \mathrm{IP}_{25}$ and $\mathrm{P}_{\mathrm{D}} \mathrm{IP}_{25}$ indices, the amount of "in-situ" phytoplankton accordingly could be overestimated due to lateral advection of biomarkers, which would result in (too) low $\mathrm{P}_{\mathrm{B}} \mathrm{IP}_{25}$ and $\mathrm{P}_{\mathrm{D}} \mathrm{IP}_{25}$ values.

The short-term variability observed in the biomarker records of core MSM5/5-712-2 during the Late Holocene (Fig. 3), however, is not reproduced by the $\mathrm{P}_{\mathrm{B}} \mathrm{IP} 25$ and $\mathrm{P}_{\mathrm{D}} \mathrm{IP}_{25}$ indices of this core. The inphase fluctuations of $\mathrm{IP}_{25}$ and phytoplankton marker contents referring to rapid advances and retreats of the sea ice margin seem to be counterbalanced through the index calculation. Coevally high amounts of $\mathrm{IP}_{25}$, brassicasterol, and dinosterol (indicating beneficial ice -edge conditions) as well as coevally low biomarker contents (suggesting an unfavourable/severe ice cover) thus give the same $\mathrm{PIP}_{25}$ values - as was already suggested by Müller et al. (2011). We hence conclude that for the proper identification of different sea ice conditions individual biomarker concentrations need to be known and accordingly interpreted.

Nonetheless, we consider these $\mathrm{PIP}_{25}$ indices to describe sea ice conditions a promising means, as they may enable a more quantitative assessment of the ice coverage (once the modern analogue calibration data set has been extended) and thus provide valuable information that can be used for e.g. palaeo freshwater budget estimates.

\section{Conclusions}

The Holocene sea ice evolution in eastern and western Fram Strait is reconstructed by means of the sea ice proxy IP $_{25}$, IRD data and the phytoplankton-derived biomarkers brassicasterol and dinosterol. In line with a lowered Northern Hemisphere insolation and decreasing temperatures, the (spring) sea ice coverage along the western continental margin of Spitsbergen increased between 8500 and 1000 years BP. In contrast, sea ice conditions at the inner shelf of East Greenland probably remained relatively constant over this period. Estimates of the sea ice conditions based on phytoplankton- $\mathrm{IP}_{25}$ indices $\left(\mathrm{P}_{\mathrm{B}} \mathrm{IP}_{25}\right.$ and $\left.\mathrm{P}_{\mathrm{D}} \mathrm{IP} \mathrm{P}_{25}\right)$ reveal a Mid Holocene shift from a reduced ice cover to marginal ice zone conditions in eastern Fram Strait, whereas the inner East Greenland shelf according to $\mathrm{PIP}_{25}$ estimates - would have experienced a predominantly marginal ice cover throughout the past 7000 years BP. During the Neoglacial, a rapidly advancing and retreating sea ice margin characterised the environmental setting at the West Spitsbergen slope. This points to a highly variable inflow of warm Atlantic Water, which, in turn, could be associated with short-term changes in the oceanic-atmospheric forcing pattern. This variability is not clearly reflected in the core from the East Greenland shelf, where only a delayed Late Holocene ice advance (i.e. a pronounced increase in $\mathrm{IP}_{25}$ contents) is observed for the past 1000 years BP. The use of $\mathrm{IP}_{25}$ and phytoplankton markers, however, proves a valuable combinatory approach for the assessment of sea surface conditions. Regarding the $\mathrm{P}_{\mathrm{B}} \mathrm{IP}_{25}$ and $\mathrm{P}_{\mathrm{D}} \mathrm{IP}_{25}$ indices we recommend that the reconstruction of sea ice coverage should not be solely based on these ratios but that individual biomarker contents need to be considered as well.

\section{Acknowledgements}

Robert Spielhagen (IFM-GEOMAR, Kiel, Germany), Christian Hass (AWI-Sylt, Germany) and Jacques Giraudeau (EPOC, Université Bordeaux 1/CNRS, France) are kindly acknowledged for providing AMS ${ }^{14} \mathrm{C}$ datings of the Maria S. Merian cores. Financial support was provided by the Deutsche Forschungsgemeinschaft through SPP INTERDYNAMIK (STE 412/24-1). We wish to thank the two anonymous reviewers for providing comments and suggestions that improved an earlier version of this manuscript.

\section{Appendix A. Supplementary data}

Supplementary data associated with this article can be found, in the online version, at doi:10.1594/PANGAEA.779628.

\section{References}

Aagaard, K., 1982. Inflow from the Atlantic Ocean to the Polar Basin. In: Rey, L. (Ed.), The Arctic Ocean. Comité Arctique International, Monaco, pp. 69-82.

Aagaard, K., Coachman, L.K., 1968. The East Greenland Current north of Denmark Strait. Arctic 21 (3), 181-200.

Alley, R.B., Mayewski, P.A., Sowers, T., Stuiver, M., Taylor, K.C., Clark, P.U., 1997. Holocene climatic instability: a prominent, widespread event $8200 \mathrm{yr}$ ago. Geology 25 (6), 483-486.

Andersen, C., Koç, N., Jennings, A., Andrews, J.T., 2004. Nonuniform response of the major surface currents in the Nordic Seas to insolation forcing: Implications for the Holocene climate variability. Paleoceanography 19, PA 2003.

Andersson, C., Risebrobakken, B., Jansen, E., Dahl, S.O., 2003. Late Holocene surface ocean conditions of the Norwegian Sea (Vøring Plateau). Paleoceanography 18 (2), 1044

Andrews, J.T., Helgadottir, G., Geirsdottir, A., Jennings, A.E., 2001. Multicentury-scale records of carbonate (hydrographic?) variability on the Northern Iceland margin over the last 5000 years. Quaternary Research 56 (2), 199-206.

Bader, J., Mesquita, M.D.S., Hodges, K.I., Keenlyside, N., Østerhus, S., Miles, M., 2011 A review on northern hemisphere sea-ice, storminess and the North Atlantic Oscillation: observations and projected changes. Atmospheric Research 101 (4) 809-834.

Bauch, H.A., Erlenkeuser, H., Spielhagen, R.F., Struck, U., Matthiessen, J., Thiede, J., Heinemeier, J., 2001. A multiproxy reconstruction of the evolution of deep and surface waters in the subarctic Nordic seas over the last 30,000 yr. Quaternary Science Reviews 20 (4), 659-678.

Belkin, I.M., Levitus, S., Antonov, J., Malmberg, S.-A., 1998. “Great salinity anomalies” in the North Atlantic. Progress in Oceanography 41 (1), 1-68.

Belt, S.T., Massé, G., Rowland, S.J., Poulin, M., Michel, C., LeBlanc, B., 2007. A novel chemical fossil of palaeo sea ice: $\mathrm{IP}_{25}$. Organic Geochemistry 38 (1), 16-27.

Belt, S.T., Massé, G., Vare, L.L., Rowland, S.J., Poulin, M., Sicre, M.-A., Sampei, M., Fortier, L., 2008. Distinctive ${ }^{13} \mathrm{C}$ isotopic signature distinguishes a novel sea ice biomarker in Arctic sediments and sediment traps. Marine Chemistry $112(3,4)$, $158-167$.

Belt, S.T., Vare, L.L., Massé, G., Manners, H.R., Price, J.C., MacLachlan, S.E., Andrews, J.T., Schmidt, S., 2010. Striking similarities in temporal changes to spring sea ice occurrence across the central Canadian Arctic Archipelago over the last 7000 years. Quaternary Science Reviews 29 (25,26), 3489-3504.

Bendle, J.A.P., Rosell-Melé, A., 2007. High-resolution alkenone sea surface temperature variability on the North Icelandic Shelf: implications for Nordic Seas palaeoclimatic development during the Holocene. The Holocene 17 (1), 9-24.

Birks, H.H., 1991. Holocene vegetational history and climatic change in west Spitsbergen - plant macrofossils from Skardtjørna, an Arctic lake. The Holocene 1 (3), 209-218.

Bonnet, S., de Vernal, A., Hillaire-Marcel, C., Radi, T., Husum, K., 2010. Variability of sea-surface temperature and sea-ice cover in the Fram Strait over the last two millennia. Marine Micropaleontology 74 (3,4), 59-74.

Boon, J.J., Rijpstra, W.I.C., Lange, F.D., de Leeuw, J.W., Yoshioka, M., Shimizu, Y., 1979. Black Sea sterol - a molecular fossil for dinoflagellate blooms. Nature 277 , 125-127. 
Bourke, R., Weigel, A., Paquette, R., 1988. The Westward turning branch of the West Spitsbergen Current. Journal of Geophysical Research 93 (C11), 14065-14077.

Broecker, W.S., 1992. The strength of the Nordic heat pump. In: Bard, E. Broecker, W.S. (Eds.), The Last Deglaciation: Absolute and Radiocarbon Chronologies. NATO Scientific Affairs Division. Springer-Verlag, Berlin Heidelberg.

Broecker, W.S., 2000. Was a change in thermohaline circulation responsible for the Little Ice Age? Proceedings of the National Academy of Sciences 97 (4), 1339-1342.

Brown, T.A., 2011. Production and Preservation of the Arctic Sea Ice Diatom Biomarker IP25. Petroleum and Environmental Geochemistry Group, School of Geography, Earth and Environmental Sciences. University of Plymouth, Plymouth, pp. 291. http://hdl.handle.net/10026.1/314.

Brown, T., Belt, S., Philippe, B., Mundy, C., Massé, G., Poulin, M., Gosselin, M., 2011. Temporal and vertical variations of lipid biomarkers during a bottom ice diatom bloom in the Canadian Beaufort Sea: further evidence for the use of the IP25 biomarker as a proxy for spring Arctic sea ice. Polar Biology 34 (12) 1857-1868.

Brown, T., Belt, S.T., 2012. Identification of the sea ice diatom biomarker IP25 in Arctic benthic macrofauna: direct evidence for a sea ice diatom diet in Arctic heterotrophs. Polar Biology 35 (1), 131-137.

Budéus, G., 2007. Short Cruise Report RV Maria S. Merian Cruise MSM05/5 University of Hamburg, Institute of Oceanography. http://www.ifm.zmaw.de/ leitstelle-meteormerian/reisen-des-fs-maria-s-merian/.

Calvo, E., Grimalt, J., Jansen, E., 2002. High resolution U37K sea surface temperature reconstruction in the Norwegian Sea during the Holocene. Quaternary Science Reviews 21 (12,13), 1385-1394.

Clarke, G.K.C., Leverington, D.W., Teller, J.T., Dyke, A.S., 2004. Paleohydraulics of the last outburst flood from glacial Lake Agassiz and the 8200 BP cold event Quaternary Science Reviews 23 (3,4), 389-407.

Damsté, J.S.S., Muyzer, G., Abbas, B., Rampen, S.W., Massé, G., Allard, W.G., Belt, S.T. Robert, J.-M., Rowland, S.J., Moldowan, J.M., Barbanti, S.M., Fago, F.J. Denisevich, P., Dahl, J., Trindada, L.A.F., Schouten, S., 2004. The rise of the rhizosolenid diatoms. Science 304, 584-587.

Deser, C., Walsh, J.E., Timlin, M.S., 2000. Arctic Sea Ice variability in the context of recent atmospheric circulation trends. Journal of Climate 13, 617-633.

Dickson, R.R., Meincke, J., Malmberg, S.-A., Lee, A.J., 1988. The "great salinity anomaly" in the Northern North Atlantic 1968-1982. Progress In Oceanography 20 (2), 103-151.

Dickson, R.R., Osborn, T.J., Hurrell, J.W., Meincke, J., Blindheim, J., Adlandsvik, B. Vinje, T., Alekseev, G., Maslowski, W., 2000. The Arctic Ocean response to the North Atlantic Oscillation. Journal of Climate 13, 2671-2696.

Dima, M., Lohmann, G., 2007. A hemispheric mechanism for the Atlantic multidecadal oscillation. Journal of Climate 20 (11), 2706-2719.

Evans, J., 2000. Late Weichselian and Holocene Sedimentation in Kejser Franz Josephs Fjord and on the Adjacent Continental Margin, East Greenland. PhD thesis, University of Cambridge, $150 \mathrm{pp}$.

Evans, J., Dowdeswell, J.A., Grobe, H., Niessen, F., Stein, R., Hubberten, H.-W. Whittington, R.J., 2002. Late Quaternary sedimentation in Kejser Franz Jospeh Fjord and the continental margin of East Greenland. In: Dowdeswell, J.A. Cofaigh, C.ó. (Eds.), Glacier-influenced Sedimentation on High-Latidtude Continental Margins. Geological Society, London, pp. 149-179.

Forwick, M., Vorren, T.O., 2009. Late Weichselian and Holocene sedimentary environments and ice rafting in Isfjorden, Spitsbergen. Palaeogeography, Palaeoclimatology, Palaeoecology 280 (1,2), 258-274.

Forwick, M., Vorren, T.O., Hald, M., Korsun, S., Roh, Y., Vogt, C., Yoo, K.-C., 2010. Spatial and temporal influence of glaciers and rivers on the sedimentary environment in Sassenfjorden and Tempelfjorden, Spitsbergen. In: Geological Society, London, Special Publications, vol 344 (1): 163-193.

Giraudeau, J., Grelaud, M., Solignac, S., Andrews, J.T., Moros, M., Jansen, E., 2010. Millennial-scale variability in Atlantic water advection to the Nordic Seas derived from Holocene coccolith concentration records. Quaternary Science Reviews 29 (9,10), 1276-1287.

Grootes, P.M., Stuiver, M., 1997. Oxygen 18/16 variability in Greenland snow and ice with 10-3 to 10-5-year time resolution. Journal of Geophysical Research 102 (C12), 26455-26470.

Hald, M., Andersson, C., Ebbesen, H., Jansen, E., Klitgaard-Kristensen, D., Risebrobakken, B.R., Salomonsen, G.R., Sarnthein, M., Sejrup, H.P., Telford, R.J. 2007. Variations in temperature and extent of Atlantic water in the northern North Atlantic during the Holocene. Quaternary Science Reviews 26 (25-28), 3423-3440.

Hald, M., Ebbesen, H., Forwick, M., Godtliebsen, F., Khomenko, L., Korsun, S., Ringstad Olsen, L., Vorren, T.O., 2004. Holocene paleoceanography and glacia history of the West Spitsbergen area, Euro-Arctic margin. Quaternary Science Reviews 23 (20-22), 2075-2088.

Hebbeln, D., 2000. Flux of ice-rafted detritus from sea ice in the Fram Strait. Deep Sea Research Part II: Topical Studies in Oceanography 47 (9-11), 1773-1790.

Hebbeln, D., Berner, H., 1993. Surface sediment distribution in the Fram Strait. Deep Sea Research Part I: Oceanographic Research Papers 40 (9), 1731-1745.

Hebbeln, D., Wefer, G., 1991. Effects of ice coverage and ice-rafted material on sedimentation in the Fram Strait. Nature 350, 409-411.

Henrich, R.d., 1998. Dynamics of Atlantic water advection to the NorwegianGreenland Sea - a time-slice record of carbonate distribution in the last 300 ky. Marine Geology 145 (1,2), 95-131.

Hjort, C., 1973. A sea correction for East Greenland. Geologiska Forenungen i Stockholm Forhandlungar 95, 132-134.
Hubberten, H.-W., 1995. Die Expedition ARKTIS-X/2 mit FS Polarstern 1994 (The Expedition ARKTIS-X/2 of RV Polarstern in 1994). Alfred Wegener Institute for Polar and Marine Research, Bremerhaven.

Huber, R., Meggers, H., Baumann, K.H., Henrich, R., 2000. Recent and Pleistocene carbonate dissolution in sediments of the Norwegian-Greenland Sea. Marine Geology 165 (1-4), 123-136.

Hughen, K.A., Baillie, M.G.L., Bard, E., Beck, J.W., Bertrand, C.J.H., Blackwell, P.G., Buck, C.E., Burr, G.S., Cutler, K.B., Damon, P.E., Edwards, R.L., Fairbanks, R.G., Friedrich, M., Guilderson, T.P., Kromer, B., McCormac, G., Manning, S., Ramsey, C.B., Reimer, P.J., Reimer, R.W., Remmele, S., Southon, J.R., Stuiver, M., Talamo, S., Taylor, F.W., van der Plicht, J., Weyhenmeyer, C.E., 2004. Marine04 marine radiocarbon age calibration, 0-26 cal kyr BP. Radiocarbon 46 (3), 1059-1086.

Humlum, O., Elberlin, B., Hormes, A., Fjordheim, K., Hansen, O.H., Heinemeier, J., 2005. Late-Holocene glacier growth in Svalbard, documented by subglacial relict vegetation and living soil microbes. The Holocene 15, 396-407.

Hurrell, J.W., Deser, C., 2009. North Atlantic climate variability: the role of the North Atlantic Oscillation. Journal of Marine Systems 78 (1), 28-41.

Hurrell, J.W., Deser, C., 2010. North Atlantic climate variability: the role of the North Atlantic Oscillation. Journal of Marine Systems 79 (3,4), 231-244.

Imhof, P., Nesje, A., Nussbaumer, S.U., 2012. Climate and glacier fluctuations at Jostedalsbreen and Folgefonna, southwestern Norway and in the western Alps from the 'Little Ice Age' until the present: the influence of the North Atlantic Oscillation. The Holocene 22 (2), 235-247.

Jennings, A., Andrews, J., Wilson, L., 2011. Holocene environmental evolution of the SE Greenland Shelf North and South of the Denmark Strait: Irminger and East Greenland current interactions. Quaternary Science Reviews 30 (7,8), 980-998.

Jennings, A.E., Knudsen, K.L., Hald, M., Hansen, C.V., Andrews, J.T., 2002. A midHolocene shift in Arctic sea-ice variability on the East Greenland Shelf. The Holocene 12 (1), 49-58.

Jessen, C.A., Solignac, S., Nørgaard-Pedersen, N., Mikkelsen, N., Kuijpers, A., Seidenkrantz, M.-S., 2011. Exotic pollen as an indicator of variable atmospheric circulation over the Labrador Sea region during the mid to late Holocene. Journal of Quaternary Science 26 (3), 286-296.

Jessen, S.P., Rasmussen, T.L., Nielsen, T., Solheim, A., 2010. A new Late Weichselian and Holocene marine chronology for the western Svalbard slope 30,0000 cal years BP. Quaternary Science Reviews 29 (9,10), 1301-1312.

Jiang, H., Seidenkrantz, M.S., Knudsen, K.L., Eríksson, J., 2002. Late-Holocene summer sea-surface temperatures based on a diatom record from the north Icelandic shelf. The Holocene 12, 137-147.

Justwan, A., Koç, N., 2008. A diatom based transfer function for reconstructing sea ice concentrations in the North Atlantic. Marine Micropaleontology $66(3,4)$, 264-278.

Kauker, F., Gerdes, R., Karcher, M., Koeberle, C., Lieser, J.L., 2003. Variability of Arctic and North Atlantic sea ice: a combined analysis of model results and observations from 1978 to 2001. Journal of Geophysical Research 108 (C6), 3182

Kierdorf, C., 2006. Variability of Organic Carbon along the Ice-covered Polar Continental Margin of East Greenland. Alfred Wegener Institute, Bremerhaven. PhD thesis, University of Bremen; urn:nbn:de:gbv:46-diss000103869.

Kleiven, H.F., Kissel, C., Laj, C., Ninnemann, U.S., Richter, T.O., Cortijo, E., 2008. Reduced North Atlantic Deep water coeval with the glacial lake Agassiz freshwater outburst. Science 319, 60-64.

Koç, N., Jansen, E., Haflidason, H., 1993. Paleoceanographic reconstructions of surface ocean conditions in the Greenland, Iceland and Norwegian seas through the last 14 ka based on diatoms. Quaternary Science Reviews 12 (2), 115-140.

Kohly, A., 1998. Diatom flux and species composition in the Greenland and Norwegian Sea in 1991-1992. Marine Geology 145, 293-312.

Kwok, R., 2000. Recent changes in Arctic Ocean Sea Ice motion associated with the North Atlantic Oscillation. Geophysical Research Letters 27 (6), 775-778.

Kwok, R., Rothrock, D.A., 1999. Variability of Fram Strait ice flux and North Atlantic Oscillation. Journal of Geophysical Research 104 (C3), 5177-5189.

Laskar, J., Robutel, P., Joutel, F., Gastineau, M., Correia, A.C.M., Levrard, B., 2004 A long-term numerical solution for the insolation quantities of the Earth. Astronomy and Astrophysics 428 (1), 261-285.

Latif, M., Böning, C., Willebrand, J., Biastoch, A., Dengg, J., Keenlyside, N. Schweckendiek, U., Madec, G., 2006. Is the thermohaline circulation changing? Journal of Climate 19 (18), 4631-4637.

Lawrence, D.M., Slater, A.G., Tomas, R.A., Holland, M.M., Deser, C., 2008. Accelerated Arctic land warming and permafrost degradation during rapid sea ice loss. Geophysical Research Letters 35 (11), L11506.

Lorenz, S.J., Kim, J.-H., Rimbu, N., Schneider, R.R., Lohmann, G., 2006. Orbitally driven insolation forcing on Holocene climate trends: evidence from alkenone data and climate modeling. Paleoceanography 21 (1), PA1002.

Lund, D.C., Lynch-Stieglitz, J., Curry, W.B., 2006. Gulf stream density structure and transport during the past millennium. Nature 444 (7119), 601-604.

Luterbacher, J., Xoplaki, E., Dietrich, D., Jones, P.D., Davies, T.D., Portis, D., GonzalezRouco, J.F., von Storch, H., Gyalistras, D., Casty, C., Wanner, H., 2001. Extending North Atlantic Oscillation reconstructions back to 1500 . Atmospheric Science Letters 2 (1-4), 114-124.

Marchal, O., Cacho, I., Stocker, T.F., Grimalt, J.O., Calvo, E., Martrat, B., Shackleton, N., Vautravers, M., Cortijo, E., van Kreveld, S., Andersson, C., Koç, N., Chapman, M., Sbaffi, L., Duplessy, J.-C., Sarnthein, M., Turon, J.-L., Duprat, J., Jansen, E., 2002. Apparent long-term cooling of the sea surface in the northeast Atlantic and Mediterranean during the Holocene. Quaternary Science Reviews 21 (4-6), 455-483. 
Massé, G., Belt, S.T., Rowland, S.T., Rohmer, M., 2004. Isoprenoid biosynthesis in the diatoms Rhizosolenia setigera (Brightwell) and Haslea ostrearia (Simonsen). Proceedings of the National Academy of Sciences of the United States of America 101 (13), 4413-4418.

Massé, G., Rowland, S.J., Sicre, M.-A., Jacob, J., Jansen, E., Belt, S.T., 2008. Abrupt climate changes for Iceland during the last millennium: evidence from high resolution sea ice reconstructions. Earth and Planetary Science Letters 269, 565-569.

Miller, G.H., Brigham-Grette, J., Alley, R.B., Anderson, L., Bauch, H.A., Douglas, M.S.V., Edwards, M.E., Elias, S.A., Finney, B.P., Fitzpatrick, J.J., Funder, S.V., Herbert, T.D. Hinzman, L.D., Kaufman, D.S., MacDonald, G.M., Polyak, L., Robock, A., Serreze, M.C., Smol, J.P., Spielhagen, R., White, J.W.C., Wolfe, A.P., Wolff, E.W., 2010. Temperature and precipitation history of the Arctic. Quaternary Science Reviews 29 (15,16), 1679-1715.

Moros, M., Andrews, J.T., Eberl, D.D., Jansen, E., 2006. Holocene history of drift ice in the northern North Atlantic: evidence for different spatial and temporal modes. Paleoceanography 21 (2), PA2017.

Müller, J., Massé, G., Stein, R., Belt, S.T., 2009. Variability of sea-ice conditions in the Fram Strait over the past 30,000 years. Nature Geoscience 2 (11), 772-776.

Müller, J., Wagner, A., Fahl, K., Stein, R., Prange, M., Lohmann, G., 2011. Towards quantitative sea ice reconstructions in the northern North Atlantic: a combined biomarker and numerical modelling approach. Earth and Planetary Science Letters 306 (3,4), 137-148.

Nesje, A., Matthews, J.A., Dahl, S.O., Berrisford, M.S., Andersson, C., 2001. Holocene glacier fluctuations of Flatebreen and winter-precipitation changes in the Jostedalsbreen region, western Norvay, based on glaciolacustrine sediment records. The Holocene 11 (3), 267-280.

NGRIP-Members, 2004. High-resolution record of Northern Hemisphere climate extending into the last interglacial period. Nature 431 (7005), 147-151.

NSIDC, Boulder, USA. http://nsidc.org/data/seaice_index/archives/, (accessed august 2010)

Overland, J.E., Wang, M., 2010. Large-scale atmospheric circulation changes are associated with the recent loss of Arctic sea ice. Tellus A 62 (1), 1-9.

Polyak, L., Alley, R.B., Andrews, J.T., Brigham-Grette, J., Cronin, T.M., Darby, D.A., Dyke, A.S., Fitzpatrick, J.J., Funder, S., Holland, M., Jennings, A.E., Miller, G.H., O’Regan, M., Savelle, J., Serreze, M., St. John, K., White, J.W.C., Wolff, E., 2010. History of sea ice in the Arctic. Quaternary Science Reviews $29(15,16)$ 1757-1778.

Porter, S.C., Denton, G.H., 1967. Chronology of neoglaciation in the North American Cordillera. American Journal of Science 265, 177-210.

Ramseier, R.O., Garrity, C., Bauerfeind, E., Peinert, R., 1999. Sea-ice impact on longterm particle flux in the Greenland Sea's Is Odden-Nordbukta region, 1985-1996. Journal of Geophysical Research 104 (C3), 5329-5343.

Ran, L., Jiang, H., Knudsen, K.L., EirÌksson, J., Gu, Z., 2006. Diatom response to the Holocene climatic optimum on the North Icelandic shelf. Marine Micropaleontology 60 (3), 226-241.

Rasmussen, T.L., Thomsen, E., Slubowska, M.A., Jessen, S., Solheim, A., Koç, N., 2007. Paleoceanographic evolution of the SW Svalbard margin $\left(76^{\circ} \mathrm{N}\right)$ since 20,000 14C yr BP. Quaternary Research 67 (1), 100-114.

Rimbu, N., Lohmann, G., Kim, J.H., Arz, H.W., Schneider, R., 2003. Arctic/North Atlantic Oscillation signature in Holocene sea surface temperature trends as obtained from alkenone data. Geophysical Research Letters 30 (6), 1280

Rimbu, N., Lohmann, G., Lorenz, S.J., Kim, J.H., Schneider, R.R., 2004. Holocene climate variability as derived from alkenone sea surface temperature and coupled oceanatmosphere model experiments. Climate Dynamics 23 (2), 215-227.

Risebrobakken, B., Jansen, E., Andersson, C., Mjelde, E., Hevrøy, K., 2003. A highresolution study of Holocene paleoclimatic and paleoceanographic changes in the Nordic Seas. Paleoceanography 18 (1), 1017.

Risebrobakken, B., Dokken, T., Smedsrud, L.H., Andersson, C., Jansen, E., Moros, M., Ivanova, E.V., 2011. Early Holocene temperature variability in the Nordic Seas: the role of oceanic heat advection versus changes in orbital forcing. Paleoceanography 26 (4), PA4206.

Rowland, S.J., Robson, J.N., 1990. The widespread occurrence of highly branched acyclic C20, C25 and C30 hydrocarbons in recent sediments and biota-A review. Marine Environmental Research 30 (3), 191-216.

Rudels, B., Friedrich, H.J., Quadfasel, D., 1999. The Arctic Circumpolar boundary current. Deep Sea Research Part II: Topical Studies in Oceanography 46 (6,7), 1023-1062.

Rudels, B., Quadfasel, D., 1991. Convection and deep water formation in the Arctic Ocean-Greenland Sea system. Journal of Marine Systems 2 (3,4), 435-450.

Sakshaug, E., 2004. Primary and secondary production in the Arctic Seas. In: Stein, R., Macdonald, R.W. (Eds.), The Organic Carbon Cycle in the Arctic Ocean. Springer-Verlag, Heidelberg, pp. 57-82.

Salonen, J.S., Seppö, H., Väliranta, M., Jones, V.J., Self, A., Heikkilä, M., Kultti, S., Yang, H., 2011. The Holocene thermal maximum and late-Holocene cooling in the tundra of NE European Russia. Quaternary Research 75 (3), 501-511.

Salvigsen, O., Forman, S.L., Miller, G.H., 1992. Thermophilous molluscs on Svalbard during the Holocene and their paleoclimatic implications. Polar Research 11 (1), $1-10$.

Sarnthein, M., Van Kreveld, S., Erlenkeuser, H., Grootes, P.M., Kucera, M., Pflaumann, U., Schulz, M., 2003. Centennial-to-millennial-scale periodicities of Holocene climate and sediment injections off the western Barents shelf, $75^{\circ} \mathrm{N}$. Boreas 32 (3), 447-461.

Schlüter, M., Sauter, E., 2000. Biogenic silica cycle in surface sediments of the Greenland Sea. Journal of Marine Systems 23 (4), 333-342.
Seppä, H., Birks, H.J.B., 2002. Holocene climate reconstructions from the Fennoscandian tree-line area based on pollen data from Toskaljavri. Quaternary Research 57 (2), 191-199.

Serreze, M.C., Barry, R.G., 2011. Processes and impacts of Arctic amplification: a research synthesis. Global and Planetary Change 77 (1,2), 85-96.

Sicre, M.-A., Jacob, J., Ezat, U., Rousse, S., Kissel, C., Yiou, P., Eiríksson, J. Knudsen, K.L., Jansen, E., Turon, J.-L., 2008. Decadal variability of sea surface temperatures off North Iceland over the last 2000 years. Earth and Planetary Science Letters $268(1,2), 137-142$.

Slubowska-Woldengen, M., Koç, N., Rasmussen, T.L., Klitgaard-Kristensen, D., Hald, M., Jennings, A.E., 2008. Time-slice reconstructions of ocean circulation changes on the continental shelf in the Nordic and Barents Seas during the last 16,000 cal yr B.P. Quaternary Science Reviews 27 (15,16), 1476-1492.

Slubowska-Woldengen, M., Rasmussen, T.L., Koc, N., Klitgaard-Kristensen, D. Nilsen, F., Solheim, A., 2007. Advection of Atlantic water to the western and northern Svalbard shelf since 17,500 cal yr BP. Quaternary Science Reviews 26 $(3,4), 463-478$

Smith Jr., W.O., Baumann, M.E.M., Wilson, D.L., Aletsee, L., 1987. Phytoplankton biomass and productivity in the marginal ice zone of the Fram Strait during summer 1984. Journal of Geophysical Research 92, 6777-6786.

Spielhagen, R.F., Werner, K., Aagaard Sørensen, S., Zamelczyk, K., Kandiano, E. Budeus, G., Husum, K., Marchitto, T.M., Hald, M., 2011. Enhanced modern heat transfer to the Arctic by warm Atlantic water. Science 331, 450-453.

Stein, R., Dittmers, K., Fahl, K., Kraus, M., Matthiessen, J., Niessen, F., Pirrung, M. Polyakova, Y., Schoster, F., Steinke, T., Fütterer, D.K., 2004. Arctic (palaeo) rive discharge and environmental change: evidence from the Holocene Kara Sea sedimentary record. Quaternary Science Reviews 23 (11-13), 1485-1511.

Steinsund, P.I., Hald, M., 1994. Recent calcium carbonate dissolution in the Barents Sea: paleoceanographic applications. Marine Geology 117 (1-4), 303-316.

Stuiver, M., Reimer, P.J., 1993. Extended (super 14) C data base and revised CALIB 3.0 (super 14) $C$ age calibration program. Radiocarbon 35 (1), 215-230.

Stuiver, M., Reimer, P.J., Bard, E., Beck, J.W., Burr, G.S., Hughen, K.A., Kromer, B. McCormac, G., van der Plicht, Johannes, Spurk, M., 1998. INTCAL98 radiocarbon age calibration, 24,000-0 cal BP. Radiocarbon 40 (3), 1041-1083.

Stuiver, M., Reimer, P.J., Reimer, R.W., 2005. CALIB 5.0 (Program and Documentation). http://calib.qub.ac.uk/calib/.

Sundby, S., Drinkwater, K., 2007. On the mechanisms behind salinity anomaly signals of the northern North Atlantic. Progress in Oceanography 73 (2) 190-202.

Svendsen, J.I., Mangerud, J., 1997. Holocene glacial and climatic variations on Spitsbergen, Svalbard. The Holocene 7, 45-57.

Swerpel, S., 1985. The Hornsund Fiord: water masses. Polish Polar Research 6, 475-496.

Trouet, V., Esper, J., Graham, N.E., Baker, A., Scourse, J.D., Frank, D.C., 2009. Persistent positive North Atlantic Oscillation mode dominated the medieval climate anomaly. Science 324 (5923), 78-80.

Trouet, V., Scourse, J.D., Raible, C.C., 2012. North Atlantic storminess and Atlantic Meridional Overturning Circulation during the last millennium: reconciling contradictory proxy records of NAO variability. Global and Planetary Change 84$85(0), 48-55$.

Vare, L.L., Massé, G., Gregory, T.R., Smart, C.W., Belt, S.T., 2009. Sea ice variations in the central Canadian Arctic archipelago during the Holocene. Quaternary Science Reviews 28 (13,14), 1354-1366.

Vare, L.L., Masse, G., Belt, S.T., 2010. A biomarker-based reconstruction of sea ice conditions for the Barents Sea in recent centuries. The Holocene. doi:10.1177/ 0959683609355179.

Vinje, T., 1977. Sea ice conditions in the European sector of the marginal seas of the Arctic, 1966-1975. Norsk Polarinstitutt Årbok 1975, 163-174.

Vinje, T., 2001. Anomalies and trends of Sea-Ice extent and atmospheric circulation in the nordic seas during the period 1864-1998. Journal of Climate 14 (3) 255-267.

Volkman, J.K., 1986. A review of sterol markers for marine and terrigenous organic matter. Organic Geochemistry 9 (2), 83-99.

Volkman, J.K., Barrett, S.M., Dunstan, G.A., 1994. C25 and C30 highly branched isoprenoid alkenes in laboratory cultures of two marine diatoms. Organic Geochemistry $21(3,4), 407-414$

Volkman, J.K., Barrett, S.M., Blackburn, S.I., Mansour, M.P., Sikes, E.L., Gelin, F., 1998 Microalgal biomarkers: a review of recent research developments. Organic Geochemistry 29 (5-7), 1163-1179.

Walker, G.T., Bliss, E.W., 1932. World weather V. Memoirs of the Royal Meteorological Society 4, 53-84.

Wanner, H., Beer, J., Bütikofer, J., Crowley, T.J., Cubasch, U., Flückiger, J., Goosse, H. Grosjean, M., Joos, F., Kaplan, J.O., Küttel, M., Müller, S.A., Prentice, I.C., Solomina, O., Stocker, T.F., Tarasov, P., Wagner, M., Widmann, M., 2008. Mid- to Late Holocene climate change: an overview. Quaternary Science Reviews 27 $(19,20), 1791-1828$

Watson, A.J., Messias, M.J., Fogelqvist, E., Van Scoy, K.A., Johannessen, T. Oliver, K.I.C., Stevens, D.P., Rey, F., Tanhua, T., Olsson, K.A., Carse, F., Simonsen, K. Ledwell, J.R., Jansen, E., Cooper, D.J., Kruepke, J.A., Guilyardi, E., 1999. Mixing and convection in the Greenland Sea from a tracer-release experiment. Nature 401 (6756), 902-904.

Werner, K., Spielhagen, R.F., Bauch, D., Hass, H.C., Kandiano, E., Zamelczyk, K., 2011. Atlantic Water advection to the eastern Fram Strait - multiproxy evidence for late Holocene variability. Palaeogeography, Palaeoclimatology, Palaeoecology $308(3,4), 264-276$ 